\title{
Effects of Unofficial Euroisation in Serbia With Regards to the Inflation and Real GDP
}

\author{
Siniša Ostojić ${ }^{1, *} \&$ Zoran Mastilo ${ }^{2}$ \\ ${ }^{1}$ University of Novi Sad, The Faculty of Economics Subotica, Department in Novi Sad, \\ Segedinski put 9-11, 24000 Subotica, Serbia \\ ${ }^{2}$ Faculty of Business Economics, University of Bijeljina, Semberskih ratara bb, 76300 \\ Bijeljina, Bosnia and Herzegovina \\ *Corresponding author: Tel: 381-63511-271 E-mail: sostojic@beotel.net
}

Received: September 10, 2013 Accepted: September 27, 2013 Published: October 23, 2013

doi:10.5296/rae.v5i4.4260 URL: http://dx.doi.org/10.5296/rae.v5i4.4260

\begin{abstract}
The term euroisation or dollarization involves several different monetary systems that are very different from one another, but have a common feature of having a foreign currency widespread as a means of payment in the formal or informal transactions. Therefore, Serbia has the highest index of unofficial euroisation in the region of South Eastern Europe. The aforementioned index demonstrates clearly the high level of informal euroisation in Serbia in the balance sheets of commercial banks. The share of dinar (RSD) corporate loans in Serbia is modest, having $77 \%$ of the total loans to corporations in Serbia being either euro-indexed or credited directly in euros. During the financial crisis in 2008 and 2009 euroisation was not reduced, but quite the contrary, it was increased and has begun gaining momentum. Despite favourable conditions for dinar loans in terms of lower inflation rate, lower interest rates on dinar loans in such conditions, but also due to the reduction of RRs required (mandatory) reserves to dinar share of commercial banks' balance sheet, the share of loans in dinars is not increased, but, on the contrary, the loan activity of commercial banks in Serbia is reduced. The current level of informal euroisation in Serbia represents a serious challenge in terms of active monetary policy, due to controlled exchange rate, lack of local funding, high foreign exchange risk and lack of hedging instruments in terms of foreign exchange risk mitigation, which are the limiting factors of an active monetary policy.
\end{abstract}

JEL: E, E4, E42, E43

Keywords: euroisation or dollarisation, unofficial euroisation 


\section{Recent Cases of Dollarisation and Euroisation}

The international monetary system has achieved great success in 1971 when the Bretton Woods system had reached its collapse. Since then, it has been generally accepted that the development of those countries whose economies are open to international capital flows shall choose between: (1) a flexible, market-formed exchange rate; and, what is known as a (2) forced binding to the currency (cash) system of another country (hard pegs) (José Luis Cordeiro, 2002). In the system of forced binding (hard pegs), the central bank implemented institutional mechanisms by which it ensures its ability to replace the foreign currency using the national currency, which then represents forced binding - hard pegs. Thus, the currency of one country is simply replaced by another currency, as a rule, it is the currency that makes the international foreign exchange reserves. Under the conditions of such forced binding, the risks of speculative attacks are less than in the case of fixed exchange rate. According to Stanley Fischer "forced binding is not sustainable, but they represent very stable systems." Only two exchange rate regimes can be analyzed in a forced binding system (hard pegs): (1) currency board, and (2) dollarisation, or euroisation. In the Monetary Board systems, the Central Bank enables storing a sufficient amount of foreign currency in the assets section of its balance sheet. Therefore, the Central Bank has a significant amount of foreign exchange reserves compared to the amount of local currency with regards to the liabilities of the Central Bank balance sheet at a fixed rate. Unlike the monetary board, a country formally adopts the currency of another country by dollarisation or euroisation. Therefore, the currency of another country becomes a legal payment method to perform a variety of transactions.

This means that some countries have given up independent monetary policy and adopted the currency of another country in order to perform all transactions (Ellen, Nikolas and Massimiliano, 2002). Although the binding to the monetary system of the other country is known as dollarisation, the process is not always based on the U.S. dollar, but also on the European euro, in which case it is renamed to euroisation. Therefore, the adoption of a country's currency by another country has its own place in the history of the world economy, but has not been used for some time. Panama has been a genuine example of official dollarisation. In 1904, Panama adopted US dollar. Such view has changed in recent years, mainly due to currency crisis present in several emerging market economies in the second half of the 1990s. The official adoption of the currency of another country eliminates the exchange rate risk, and that risk destabilized the entire macroeconomic system. By eliminating the risk of exchange rate fluctuations through dollarisation / euroisation excludes the potential cause of the currency crisis in such economies. That way, the official and unilateral dollarisation/euroisation have become a common feature of such economies. Five countries or territories have adopted the currencies of other countries in recent years: Montenegro and Kosovo in the Western Balkans, while in Latin America, Ecuador and El Salvador decided to abandon its currency and accept U.S. currency, the same as East Timor, which has been effectively dollarised after obtaining independence. Likewise, Monaco, a small country on the southeast coast of France, renowned for being the meeting place of rich and wealthy people, adopted the French franc in 1865, but uses European euro as the 
payment currency today. That is the reason why this process was named euroisation. Monaco is a small country with an area of less than $80000 \mathrm{~km}^{2}$, with about 30000 inhabitants. In October 2000, Andorra passed the law on the introduction of euro. Liechtenstein adopted Swiss franc as legal tender back in 1924, after several unsuccessful attempts to form their own currency. In these countries, the rate of employment growth is far higher than in neighboring European countries. These countries have highly open economies and the sum of exports and imports to GDP ranges from $100 \%$ in Andorra to $200 \%$ in Liechtenstein (Klauser, 2001). The banking sector is another important pillar in which they relied in developing their economies, so that in Monaco, which is the most developed financial center of these microstates, $90 \%$ of the banks' clients are non-resident, that is, prosperous and wealthy people outside Monaco. Unlike Monaco, Andorra and Liechtenstein, Ecuador has 13, 000,000 residents and extends to over $180000, \mathrm{~km}^{2}$. In 1999 Ecuador faced a number of very difficult financial crises. Gross domestic product (GDP) in Ecuador decreased by more than $7 \%$, with the inflation rate increasing to over $50 \%$ per month, the banking system collapsed, and sucre (the currency) was losing value so that, in a year, it lost a $2 / 3$ of its value against the U.S. dollar. Specifically, Ecuador faced annual inflation of more than $30 \%$ per year. The budget deficit was modest, but current account showed a negative balance and external debt rose to about 95\% of GDP (Winkler, Adalbert, Mazzaferro, Francesco, Nerlich, Carolin and Thimann, Christian, 2004). Late in 1999, the national currency sukru again experienced tremendous pressure at the foreign exchange market, and it depreciated from 11000 Sucre for one US\$, to 24825 (sucre) for one US\$. This was followed by the political instability, and then the Ecuadorian government decided to introduce the USA dollar as the legal tender at a fixed conversion rate of 25000 (sucre) for one USD. In January 2000, the monetary authorities of Ecuador bonded their monetary system to the U.S. monetary system and adopted the U.S. dollar as legal tender. In just 6 months, the Central Bank of Ecuador withdrew the entire amount of local currency "sucre" from the market. Almost instantaneously, the interest rates were reduced and the banking sector started to operate again. Inflation was brought down, and the GDP continued to grow. Dollarisation process in Ecuador was carried out successfully and in just one year, Ecuador fully introduced the U.S. dollar as legal tender.

Table 1: Selected Macroeconomic Indicators of Equador

\begin{tabular}{lcccc}
\hline & $\begin{array}{c}\text { Average } \\
1970-1979\end{array}$ & $\begin{array}{c}\text { Average } \\
1980-1990\end{array}$ & $\begin{array}{c}\text { Average } \\
1990-1999\end{array}$ & 1999 \\
\hline The growth rate of GDP & 9.2 & 2.4 & 1.9 & -7.5 \\
The growth rate of GDP per capita & 5.8 & 0.2 & -0.3 & -9.2 \\
inflation & 11.9 & 34.0 & 39.0 & 52.2 \\
Exchange rate of sucre compared to the & 25 & 175 & 4636 & 20243 \\
US dollar & & & & \\
The real effective exchange rate & n.a & 143.8 & 92.8 & 80.3 \\
Budget deficit as \% of GDP & -1.8 & -1.5 & 0.5 & -0.7 \\
Current account balance as \% of GDP & -5.3 & -5.4 & -3.4 & 6.7 \\
External debt as \% of GDP & 30.7 & 80.2 & 94.8 & 81.2 \\
\hline
\end{tabular}


Source: Winkler, Adalbert, Mazzaferro, Francesco, Nerlich, Carolin and Thimann, Christian, Official Dollarisation/Euroisation: Motives, Features and Policy Implications of Current Cases (February 2004). ECB Occasional Paper No. 11. SSRN: http://ssrn.com/abstract $=748975$

A neighbouring country Panama began the process of dollarisation in 1904. year. With a population of 3.4 million inhabitants, Panama is by far the largest politically independent state which has implemented the introduction of the U.S. dollar as the national currency. After gaining independence from Colombia in 1903. The Banco Nacional de Panama (BNP), is a state-owned credit institution established by law in 1904. It operates as a financial agent of the central government and is the official clearing house of the banking sector and provides the adequate supply of U.S. notes and coins to the banking system. International long-term bonds are traded in Panama at a risk premium of 400-500 basis points in relation to U.S. Treasury bonds, which is much higher than the bonds of other sovereign Latin American countries, such as Chile with similar maturities. According to Juan Luis Moreno-Villalaz, "Panama's macroeconomy is characterized by dollarisation, full financial integration, and specialization in service exports. These features are at the core of a consistent free-market institutional system that has produced a stable economic order and an efficient macroeconomic adjustment mechanism. This experience contrasts with other emerging markets that typically rely on macro-management or policy action and have a record of macroeconomic instability" The U.S. dollar has been Panama's legal tender for 100 years. Successive governments have chosen to maintain this "self-denying ordinance" because the dollar anchor has given the country a degree of monetary stability. The absence of a central bank ensures no monetary intervention, so Panama essentially has a private monetary system in which the stock of money is determined by the decisions of private agents and banks. The unified currency system eliminates foreign exchange risk, currency mismatches, and speculative attacks so common in other countries with central banks and "sovereign" money. The absence of "policy decisions" regarding monetary or exchange rate affairs reduces risk because less information is needed by outside investors. (Juan, 2005) Monetary stability in Panama (Sebastian, 2001) is exceptional compared to most countries in the region. For example, inflation rates were lower than in the United States. The selected macroeconomic indicators of Panama are shown in the following table:

Table 2: Selected Macroeconomic Indicators of Panama

\begin{tabular}{lccc}
\hline & $\begin{array}{c}\text { Average } \\
1970-1979\end{array}$ & $\begin{array}{c}\text { Average } \\
1980-1990\end{array}$ & $\begin{array}{c}\text { Average } \\
1990-1999\end{array}$ \\
\hline The growth rate of GDP & 4.7 & 0.9 & 5.1 \\
The growth rate of GDP per capita & 2.4 & -1.0 & 2.9 \\
Inflation & 6.0 & 3.1 & 1.1 \\
Budget deficit as \% of GDP & -7.3 & -5.1 & -4.3 \\
Current account balance as \% of GDP & n.a. & -0.11 & -3.3 \\
External debt as \% of GDP & 57.1 & 99.7 & 94.9 \\
\hline
\end{tabular}

Source: Winkler, Adalbert, Mazzaferro, Francesco, Nerlich, Carolin and Thimann, Christian, 
Official Dollarisation/Euroisation: Motives, Features and Policy Implications of Current Cases (February 2004). ECB Occasional Paper No. 11. SSRN: http://ssrn.com/abstract $=748975$

As a fully dollarised economy, Panama (IMF Country Report, 2012) has neither a central bank nor a Creditor, as opposed to some other economies that are fully dollarised such as El Salvador. Likewise, no mandatory reserves instrument or a deposit insurance system exist or function, which is why the commercial banks in Panama keep a relatively high level of liquidity as a form of self-insurance. During the financial crisis of 2008-09 several commercial banks in Panama have experienced a lack of liquidity due to the sudden freezing of foreign credit lines. In addition, the state bank, the National Bank of Panama established a collateral line of credit in the amount of 400 million U.S. \$ to replace some of the failed export businesses. In January 2009, the Government established the Fund for liquidity (PEF) for a total amount of 1.1 billion U.S. $\$$ which is about $5 \%$ of total deposits, to finance productive investments and working capital. The Fund is funded by the Interamerican Development Bank in the amount of U.S.\$500 million and the Andean Development Corporation U.S.\$ 210 million. However, due to the high interest rate and uncertainty regarding the acceptance of collateral, caused PEF to approve only $\$ 100$ million US\$ before being shut down. Otherwise, the inflation in Panama during the crisis years from 2008 to 2012 was respectively: $6.8 \%, 1.9 \%, 4.9 \%, 6.3 \%$ and $5.7 \%$.

Likewise, Salvador became the third Latin American country that has abandoned its currency and adopted the U.S. dollar as legal tender on $1^{\text {st }}$ January 2001. Ecuador was dollarised in September 2000, while Panama has been using the U.S. dollar since 1904. The Law on Monetary Integration in El Salvador had a significant impact on economic growth and the daily life of the citizens of Salvador (David \& William, 2003).

Table 3: Selected Macroeconomic Indicators of Salvador

\begin{tabular}{lcccc}
\hline & $\begin{array}{c}\text { Average } \\
1970-1979\end{array}$ & $\begin{array}{c}\text { Average } \\
1980-1990\end{array}$ & $\begin{array}{c}\text { Average } \\
1990-1999\end{array}$ & 1999 \\
\hline The growth rate of GDP & 3.9 & -1.9 & 4.7 & 2.0 \\
The growth rate of GDP per capita & 1.9 & -3.5 & 2.4 & -0.1 \\
Inflation & 9.4 & 18.5 & 10.6 & 0.5 \\
Colones exchange rate against the & 2.5 & 3.5 & 8.6 & 8.75 \\
dollar USA & & & & \\
Budget deficit as \% of GDP & -0.4 & -2.8 & -1.7 & -2.3 \\
Current account balance as \% of & -0.6 & -1.0 & -0.3 & -0.2 \\
GDP & & & & 32.8 \\
External debt as \% of GDP & 22.3 & 45.9 & 33.2 & 32 \\
\hline
\end{tabular}

Source: Winkler, Adalbert, Mazzaferro, Francesco, Nerlich, Carolin and Thimann, Christian, Official Dollarisation/Euroisation: Motives, Features and Policy Implications of Current Cases (February 2004). ECB Occasional Paper No. 11. SSRN: http://ssrn.com/abstract $=748975$ 
"Dollarisation" refers to the de facto or de jure adoption of the U.S. dollar as a foreign country's currency of choice for small- and large-scale economic transactions. Though dollarisation does not necessarily require the replacement of local currencies, the modern trend is toward replacement rather than coexistence. Replacing a country's currency with the U.S. dollar entails a sacrifice of the government's money-issuing function. In effect, El Salvador (like Ecuador and Panama before it) has elected to turn monetary policy over to the United States Federal Reserve (David \& William, 2003). Likewise, during the global financial crisis, Salvador had a pronounced liquidity risk. Therefore, after the crisis of 2008 and 2009, the authorities of El Salvador were engaged in establishing a fund for liquidity and LOLR as a segment of a comprehensive strategy for liquidity management. It has been foreseen that the Liquidity Fund is financed from current mandatory reserves in the amount of $3 \%$ on deposits and LOLR should be able to provide long-term liquidity and solvency of the banking sector within 4 years, where the percentage of payments would be $8 \%$ of the total amount of deposits. (IMF Country Report, 2012)

Unlike these countries, Montenegro, Kosovo and East Timor, have adopted a foreign currency in the immediate post-conflict situation that led to independence or to a newly defined political status. After the war, in June 1999, The United Nations Mission in Kosovo (UNMIK) established DM as local currency. Since 2002, the economy has fully adopted the euro, and the Central Bank was founded in November 1999 with the goal to establish efficient and secure payment system as well as to ensure the liquidity and solvency of the banking system. In November 1999. the Montenegrin Government has unilaterally declared the Deutsche Mark as legal tender in parallel with the Yugoslav dinar, which has been operating in Serbia. In January 2001 the Deutsche Mark became the legal tender, and since 2002 the Montenegrin economy has fully adopted the euro. The Central Bank of Montenegro is responsible for establishing and maintaining liquidity of the banking system and efficient payment system and works as a financial agent of the Government of Montenegro. Otherwise, in Central, Eastern and South-Eastern Europe (CESS), the use of foreign currencies, and particularly of euro, is widespread, which is why this process is called euroisation. There are several reasons for the occurence of euroisation, as we see from the examples of Kosovo and Montenegro, some of the reasons refer to the history of the country in terms of erosion of confidence in the national currency caused by political and economic turbulences. Other problems of solid binding to the euro are likely related to the countries' current or future situation in terms of closeness of economic links with the euro zone, migration, and expectations regarding the introduction of euro. In their research, (Petrakos, 2001) and. Kirkilis D (2001). pointed to the fact that the most important trade partner of these countries at the beginning of transition was the EU. Over $50 \%$ of the total foreign trade of the countries has been done with the EU. Also, when considering foreign direct investment, most of such investments comes from the euro-zone countries (Rizopoulos, 2001). However the most important is that in 1999, when Kosovo and Montenegro opted for euroisation, annual inflation was 42\% (IMF, 2001e). Euroisation in Kosovo and Montenegro came after two decades of high monetary instability and after the operation of unofficial euroisation when the Deutsche mark was used as a conservation currency and as a medium of exchange. In both Kosovo and Montenegro, the inflation after the introduction of the official euroisation 
has been rapidly reduced. In year 2000, the inflation in Kosovo was 10.0\%, in $200113.6 \%$, in 2002 it was 3.6\%, while it was slightly higher in Montenegro and reached $36.1 \%, 21.8 \%$ and $16.8 \%$ respectively.

\section{The Euroisation / Dollarisation Process - A Literature Review}

The term euroisation or dollarisation involves several different monetary systems that are very different from each other but have a common feature of having a foreign currency widespread as a means of payment in the formal or informal transactions. Indeed, the two most widely used currencies are U.S. dollar and euro. For example, Bogetić Ž defined euroisation / dollarisation in a way that "the dollarisation is a diversification of the portfolio from a domestic currency into a foreign currency because of the fact that the domestic currency does not represent a measure of value, billing unit and a medium of exchange." A Alexandre Minda (Alexandre, 2005) perceives dollarisation / euroisation in the strict sense of the word as simply disposing of your own national currency and adopting other currencies. He also quotes the definition given by Salama P. at which dollarisation implies that the dollar is the dominant means of value, billing unit, and medium of exchange for certain products and services. Dollarisation is usually due to unstable macroeconomic conditions and the rational response of individuals who wish to diversify their assets when faced with increased foreign exchange risk of their own national currency. Unlike them, Levy Yeyati (Eduardo Levy-Yeyati, 2004) defines financial dollarisation process as simply holding of a foreign currency by the residents of a country and denomination of assets and liabilities in foreign currency, including bank loans and deposits, as well as non-banking assets such as commercial securities and government securities. The process of euroisation/dollarisation can be spontaneous, partial and unofficial, while reflecting the preferences of individuals in the demand for foreign currency, or it can be complete in the sense that the country adopts a foreign currency as an exclusive or a parallel legal tender. A number of factors contributed to having some Eastern European countries showing interest in official dollarisation/euroisation. Likewise, Stephen Slivinski perceives euroisation / dollarisation as a takeover of foreign currency instead of local currency followed by having the foreign currency taking over the function of money as a measure of value, an accounting function and a medium of exchange usually the U.S. dollar or European euro. Slivinski distinguishes official dollarisation / euroisation, which according to him arises when a country adopts a foreign currency as legal tender, while nevertheless, he differs unofficial dollarisation, which occurs when foreign currency is not an officially legal tender. In fact, according to him, unofficial dollarisation arises when citizens prefer any other currency than local currency. Although the data on unofficial dollarisation is difficult to recover, Edgar Feige presented some information for each country on unofficial dollarisation index measured as the amount of participation of foreign currency in the money supply. For example, percentages of unofficial dollarisation are: Argentina $68.8 \%$, Armenia 45.3\%, Belarus 58.9\%, Bolivia 83.5\%, Bulgaria 55.6\%, Costa Rica 47.5\%, Croatia 72.7\%, Czech Republic 25.9\%, Estonia 17.4\%, Hungary 20.6\%, Kyrgyzsan 41.4\%, Latvia 48.7\%, Lithuania 31.5\%, Mexico 25.8\%, Nicaragua 76.4\%, Peru $57.5 \%$, Poland 18.0\%, Romania 36.1\%, Russia 72.6\%, Turkey 46.7\%, Ukraine 44.9\%, 
Uruguay 74.1\%, Venezuela 18.0\% (Feige \& James, 2004). Almost identical definition of euroisation / dollarisation is given by Eduardo Levy-Yeyati (2004), with financial dollarisation being the keeping denominated assets and liabilities, including bank deposits and loans, as well as non-banking assets such as commercial paper or government bonds, by the residents of a country. The descriptive nature of this definition implicitly recognizes that the presence of foreign currencies is the result of a weak domestic currency, namely the domestic currency ceases to perform the function of a measure of value. Euroisation / dollarisation is a common feature in many developing economies and economies in transition, i.e. the countries of Central and Eastern Europe, as noted by Anne-Marie Gulde, David Hoelscher, Alain Ize, David Marston, and Gianni De Nicoló (2004) particularly referring to the impact of euroisation / dollarisation onto the financial stability of the economy. In an effort to promote financial stability, financial services, and deepen the financial system, many economies around the world openly encourage financial dollarisation / euroisation through the use of foreign currency. However, the recent rapid growth in dollarised economies, as well as accompanying visible problems in euroised / dollarised economies of Central and Eastern Europe, suggest further expansion of financial dollarisation, including the creation of a compromise between economic development and financial stability. The authors also make a clear distinction between certain types of dollarisation / euroisation. Thus, they believe that dollarisation / euroisation can take multiple forms. There is an official (de jure) dollarisation, which occurs when the U.S. dollar is adopted as the dominant or exclusive legal tender. The dollarisation might be partial (de facto), and it occurs when the domestic currency remains the only means of payment, but financial transactions can be conducted in dollars / euros, which means that, effectively, a dual currency system is in function. Likewise, it would be useful to distinguish a financial dollarisation of an economy where residents keep their financial assets and their financial liabilities in a foreign currency, from a payment dollarisation when foreign currency is used to conduct transactions, as well as from a real dollarisation, represented by formal indexing or or de facto indexing of local prices and salaries in comparison to the US \$ / euro. Besides, the aforementioned authors classify financial dollarisation as follows: a financial dollarisation may be domiciled when the dollar is used to express claims between residents of a country, and it can be external when the dollar used to express claims between residents of one country and non-residents of that country (Gianni, Patrick \& Alain, 2003). Since the U.S. dollar is the dominant currency, and it is used in a dual-currency system, other currencies may also be used to supplement the local currency. Therefore, the term "dollarisation" should be taken in the generic sense. Also, the authors emphasize that partial dollarisation / euroisation affects a large number of transition countries, Latin America, Africa, Asia and the Middle East. 
Table 4: The Average Share of Foreign Deposits in Total Deposits (in \%)

\begin{tabular}{lccccccc}
\hline Regions & $\begin{array}{c}\text { Number of } \\
\text { Countries }\end{array}$ & 1996 & 1997 & 1998 & 1999 & 2000 & 2001 \\
\hline South America & 8 & 45.8 & 46.1 & 49.4 & 53.2. & 54 & 055.9 \\
Transition economies & 26 & 37.3 & 38.9 & 43.5 & 44.3 & 46.9 & 47.7 \\
Middle East & 7 & 36.5 & 37.2 & 37.7 & 37.5 & 38.2 & 41.9 \\
Africa & 14 & 27.9 & 27.3 & 27.8 & 28.9 & 32.7 & 33.2 \\
Asia & 13 & 24.9 & 28. & 026.8 & 28.8 & 28.7 & 28.2 \\
Central America and Mexico & 7.0 & 20.6 & 20.8 & 22 & 22.1 & 22.5 & 24.7 \\
Caribbean & 10 & 6.3 & 7.6 & 6.8 & 6.7 & 6.1 & 6.2 \\
Industrial countries & 140 & 7.4 & 7.5 & 7.5 & 6.7. & 7 & 6.6 \\
\hline
\end{tabular}

Gianni De Nicoló, Patrick Honohan, and Alain Ize (2003)

The same conclusion is drawn by M. Ivanov, M. Tkalec, M. Vizek (2011), who note that the origin of the informal financial euroisation in most of the post-transition economies can be observed since 1980. Despite the economic and political stability, improvement of the strong macroeconomic performance in these economies and the increased credibility of the central bank, financial euroisation is increasingly becoming more common in the post-transition economies. In particular, a financial risk demonstrated in these economies is the exchange rate risk, which strongly influenced the destabilization of the financial system, followed by a destabilisation of the economic growth due to inflation. The creators of economic and monetary policy in the post-transition EU accession did not insist that the financial system is released of any euro influence, because of the assumption that the adoption of euro is inevitable in economies that aspire to join the European Monetary Union, which in return implies that the Financial Euroisation is an implied necessity. However, in Serbia, the reasons for euro domination are not only related to the membership in the European Union, nor in the fact that the European economies are the most important trade partners of Serbia, but are, as mentioned by Poul M. Thomsen (2010) and Michele Shannon (2010), the reasons for euro domination and high euroisation roots in Serbia date from the early years of the disintegration of Yugoslavia, and they include: (i) a long history of high and unstable inflation, (ii) the prior policy which favoured the euro too much, including the repayment of frozen foreign currency savings, but not repayment of savings deposited in dinars, (iii) loss of confidence in government fiscal obligations to keep the inflation at a low level often influenced the sharp shifts in economic policy, (iv) lack of currency hedging to reduce exposure to foreign exchange risk, (v) and underdeveloped local currency market, meaning that a minor increase of Serbian dinar supply immediately depreciates the exchange rate Serbian dinar / euro. Such high Euroisation level of financial systems of Central and Eastern Europe economies was indicated by Piritta Sorsa (2006) when presenting performance of financial systems in selected transition economies. The reform of the financial sector made strong progress in many economies of the region, and such reformed financial sector has strongly contributed to the economic growth and a functioning market economy. In most economies in the region, the restructuring and privatization in the region strongly influenced the increased presence of foreign banks, particularly those from the European Union. Nearly all of the funds are 
allocated to banks, which are privately owned or owned by foreign banks, as was the case in Albania, Bosnia and Herzegovina, Croatia, while in Romania and Serbia the progress in the reform of the financial system was registered by 2006, but the share of private banks in total assets was still about $50-60 \%$ of the total number of banks. The privatization of banks has increased the confidence in the banking sector, which increased monetization of the banking sector and led to the growth of the deposit structure in the bank financing structure. However, the degree of dollarisation of deposits is very high in relation to total deposits which already indicated a high degree of informal euroisation / dollarisation. Bank privatization has affected the credit boom, but even the loans were mainly granted with a foreign currency clause, or directly in euros or other currencies, particularly in Swiss francs. Both the deposit and loan portfolio of banks was already unofficially euroised. That means that the citizens mainly saved money in euros and the loans granted to them were in Euros because the domiciled currency in these economies only served as a means of payment, but it did not serve as a mean to preserve the value and credit function.

Table 5: Indicators of Financial Sector Euroisation in the Economies of South East Europe $2004($ in $\%)$

\begin{tabular}{cccccc}
\hline & $\begin{array}{c}\text { M2/GDP } \\
\text { ratio }\end{array}$ & $\begin{array}{c}\text { Dollarisation } \\
\text { of deposits }(\% \\
\text { from total } \\
\text { deposit) }\end{array}$ & $\begin{array}{c}\text { Dollarisation } \\
\text { loans }\end{array}$ & $\begin{array}{c}\text { Credit/GDP } \\
\text { ratio }\end{array}$ & $\begin{array}{c}\text { Interest rate } \\
\text { spred }\end{array}$ \\
\hline Bulgaria & 50 & 48 & 7.0 & 37 & 6.1 \\
Romania & 27 & 41 & 8.1 & 17 & 13.7 \\
Croatia & 68 & 87 & 4.5 & 57 & 10.1 \\
Macedonia & 31 & 50 & 8.5 & 24 & 5.5 \\
Albania & 50 & 30 & 4.5 & 10 & 6.5 \\
Montenegro & & 100 & & & \\
Serbia & 21 & 70 & 23.0 & 20 & 11.0 \\
Bosnia & 51 & 50 & 3.3 & 45 & 7 \\
\hline
\end{tabular}

Source: Piritta Sorsa, (2006) "Macroeconomic Challenges with EU Accession in Southeastern Europe: An Overview" IMF Working Paper WP/06/40

The level of euroisation / dollarisation in Serbia over the following few years has been increased and Serbia has become the leading country in the region according to the euroisation level of its economy (International Monetary Fund, The World Bank, marsh 2010). Thus, according to the Austrian Central Bank (OeNB) level of euroisation / dollarisation in Serbia, compared to other economies in the region, is the highest and what is interesting is that even after realisation of sound macroeconomic performance of Serbian economy, Euroisation / dollarisation level has not been reduced but completely the opposite the euroisation level has been increased. The outbreak of the global recession and financial crisis has led to the worsening prospects of economic growth in the economies of South East Europe, with a strong risk of stopping their economic growth and rapid depreciation of their domicile currency. The risk of sudden devaluation or depreciation of the local currency was 


\section{Macrothink Institute ${ }^{\mathrm{TM}}$}

particularly pronounced in those economies where the obligations to foreign creditors are denominated in foreign currencies. However, after the sudden rise of euro and the strong depreciation of the national currencies of these economies on their national currency markets, there has been an easing of foreign exchange rates, and it can be concluded that between the year 2007 and 2010, the currencies of South-Eastern Europe economies have depreciated between 3\% and 15\%. However, the net capital flow in 2008-2009 abruptly dropped by more than $10 \%$ of GDP, especially in Hungary, Croatia and Romania. The only capital inflows which remained stable were in the Czech Republic (Jan \& Aasim, 2011). Therefore, the depreciation of the national currency exchange rate has affected the growth of debt of the loan applicants and forced further pressure to increase informal euroisation. The currency structure of private sector loans in selected economies is displayed in the following figure.

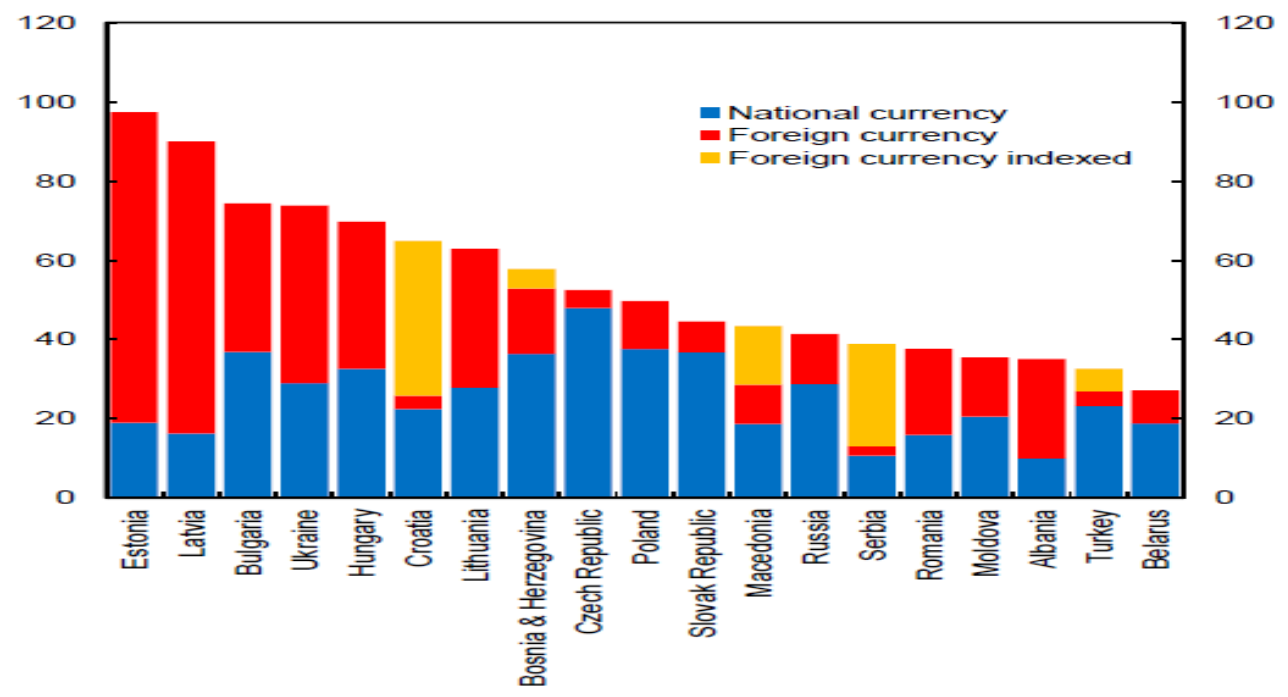

Figure 1: The Currency Structure of Loans Granted to the Private Sector in Post-transition Economies, in year 2008. Source OeNB, October 2009

In addition, recent data collected by the Central Bank of Austria (OeNB) show that the level of euroisation in Serbia is the highest compared to other countries of Eastern Europe, but also the most widespread in terms of share of deposits $(88 \%)$ and cash holdings of the population (75\%). 


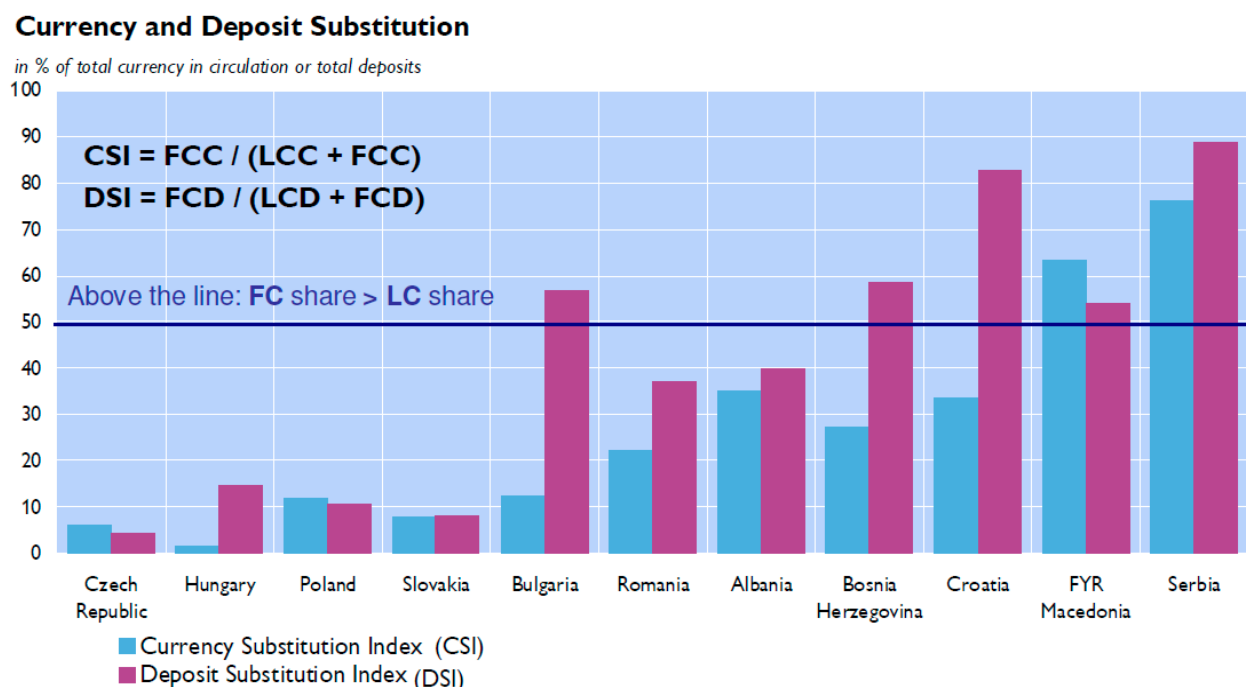

Figure 2: Currency and deposit substitution in selected economies of South East Europe. Source OeNB, October 2009

The currency substitution index is given by the following equation (Economic Overview of the National Bank of Serbia, April, 2003)

$$
\text { Currency in Circulation Index }=\frac{\text { ForeignCurrencyin Circulation }}{\text { (LocalCurrencyin Circulation + ForeignCurrencyin Circulation }}
$$

Unlike other regional economies, Serbia's share of foreign currency is almost identical to the amount of deposited money. Therefore, Serbia has the largest euroisation index in the region of South Eastern Europe, as demonstrated by the Austrian central bank OeNB, and it demonstrates very well the high euroisation level in Serbia in the balance sheets of commercial banks. The portion of dinar-related loans to corporations is quite modest, $77 \%$ of the total loans granted to corporations in Serbia are either euro-indexed or credited directly in euros. During the financial crisis in 2008 and 2009, euroisation was not reduced, but quite the contrary it was increased and even gained momentum. Despite favourable conditions for dinar loans in terms of lower inflation, lower interest rates on loans in dinars in such conditions, but also due to the lowering of RRs reserves to the dinar liabilities of the balance sheets of commercial banks, the share of loans in dinars was not increased. On the contrary, the credit activity of commercial banks in Serbia has been reduced. That means that the more stringent payment obligation of RRs banks' mandatory reserves on the basis of euro liabilities in Serbian dinars, increases the dinar share of the commercial banks' balance sheet assets. Increasing the share of dinar assets of commercial banks does not imply in advance that the dinar potential for the approval of dinar loans shall be improved. As indicated by the following chart with data that demonstrates a reduction in loans and a growth of deposits directly in euros. 


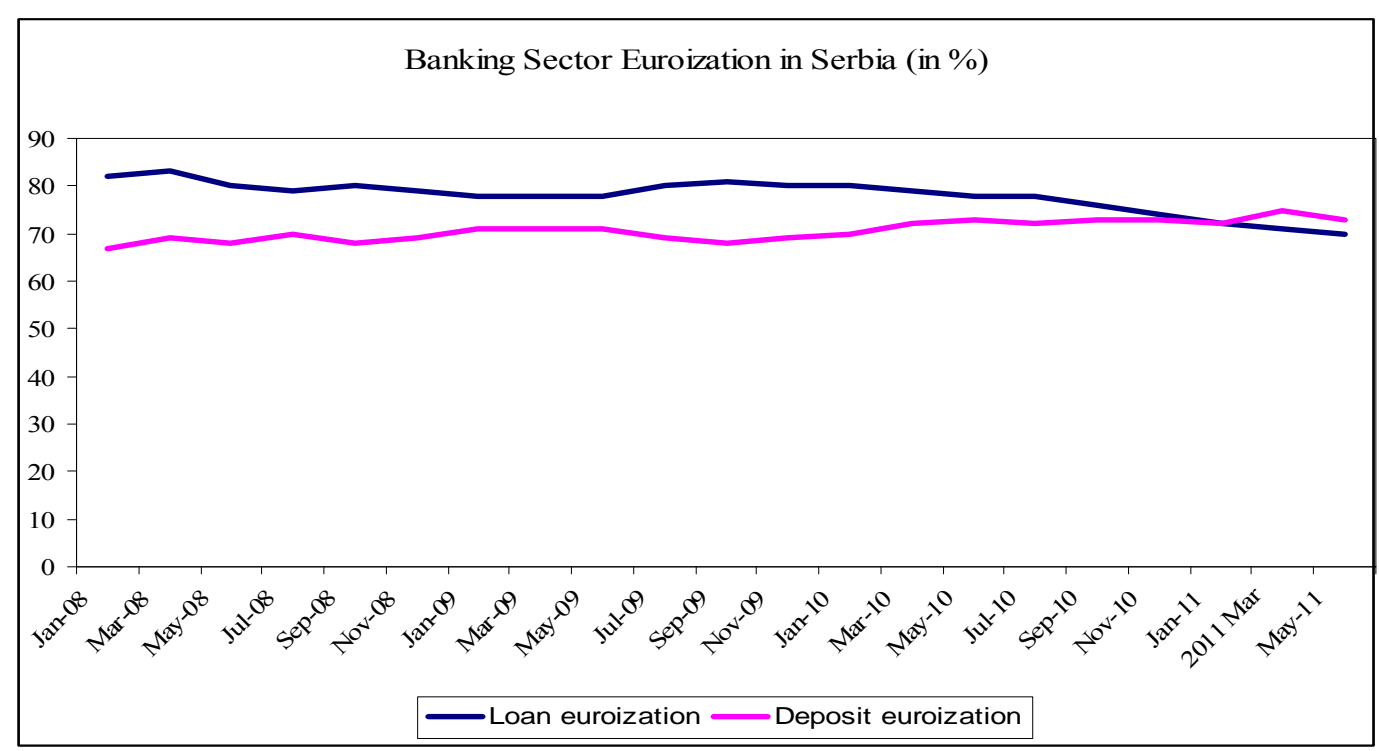

Figure 3: Euroisation of Loans and Deposits in Serbia 2008-2010.

Source: Republic of Serbia: Request for Stand-By Arrangement, IMF Country Report No.

$$
11 / 311 \text {. }
$$

Greater dinar share in assets of the commercial banks' balance sheets later affects the change of the assets structure of the National Bank of Serbia (NBS) so that commercial banks purchase Treasury bonds from the Ministry of Finance of the Republic of Serbia and appear in the REPO open market operations managed by NBS. This is shown by the following chart referring to the level of general euroisation in South-Eastern Europe economies.

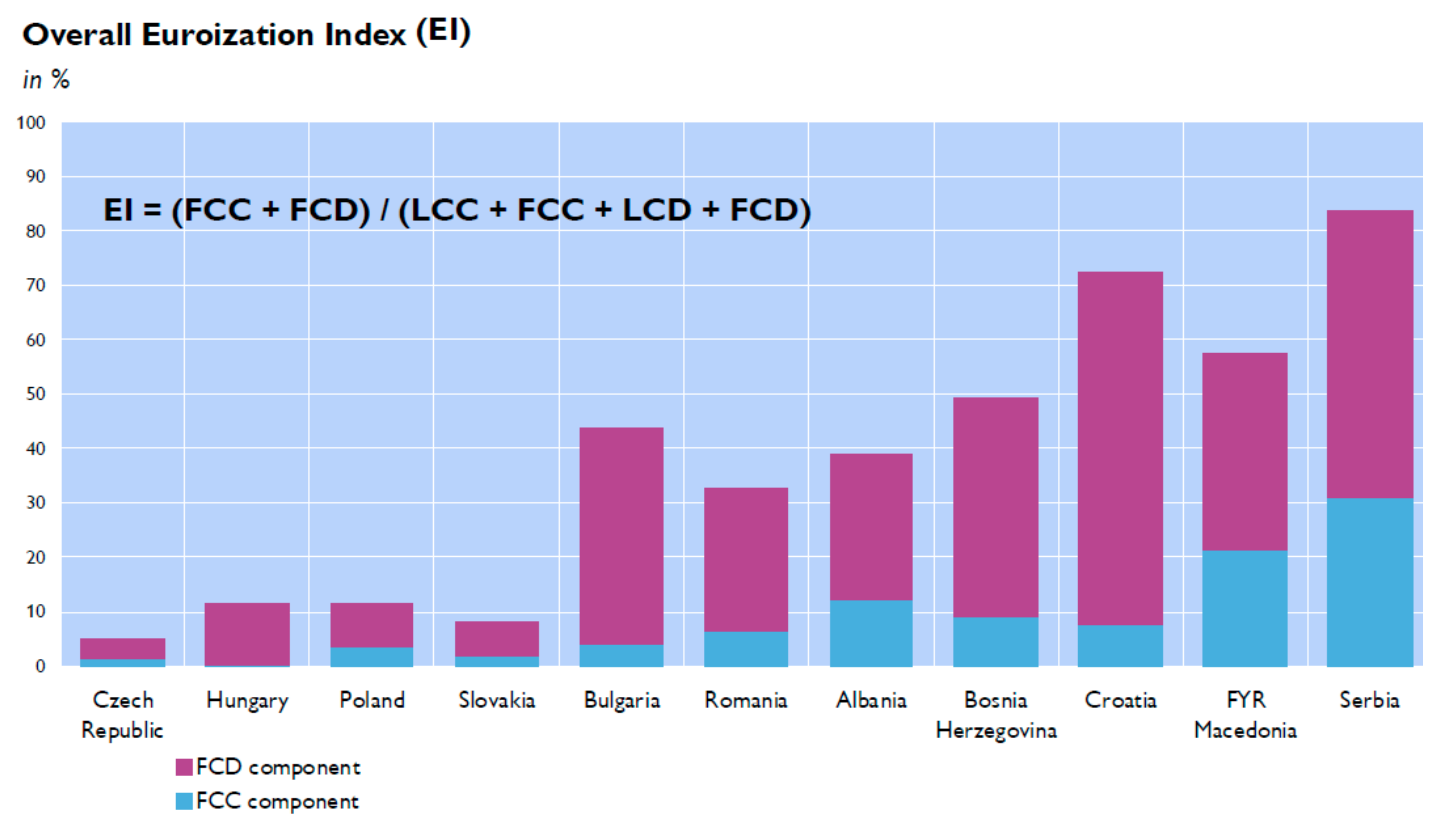

Figure 4: Overall Euroisation Index - OeNB, October 2009

What even more indicates a high degree of euroisation/dollarisation in selected economies is the fact that the loans granted directly approved or indexed in foreign currency, are again dominated by euro, as indicated by Peter R. Haiss and Wolfgang Rainer (Peter \& Wolfgang, 


\section{Macrothink}

2009).

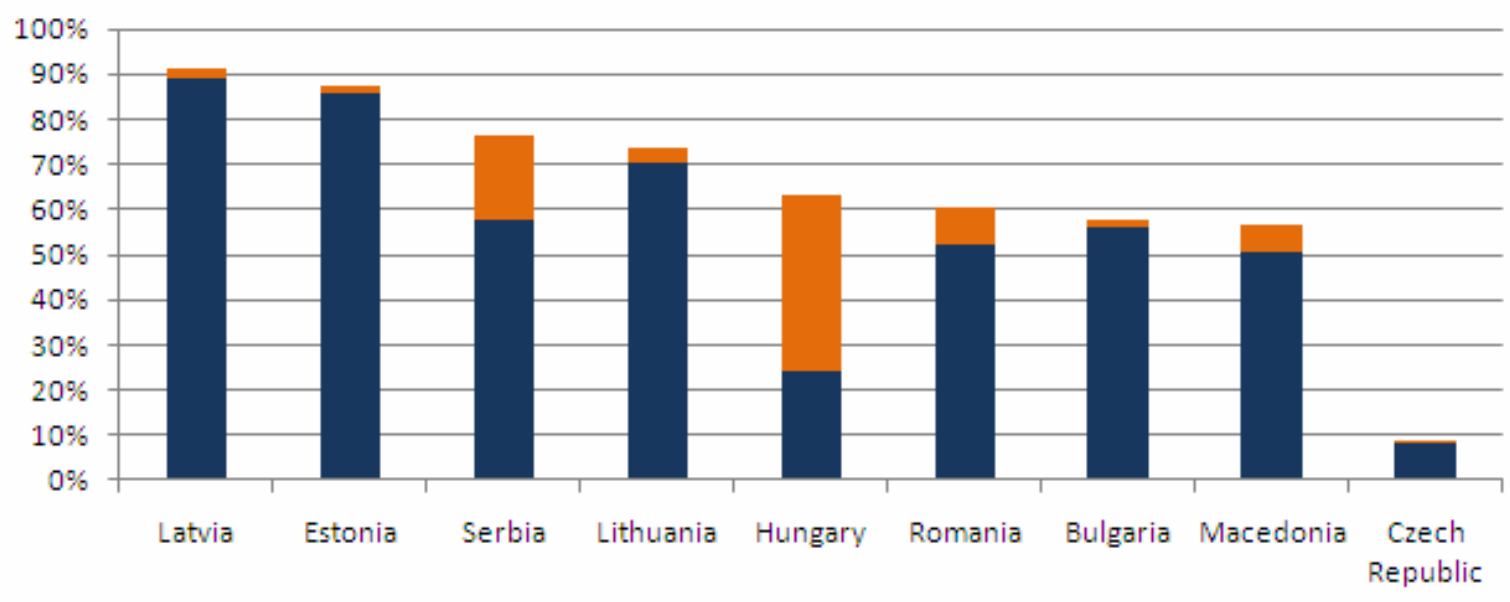

a EUR O Other currencies

Figure 5: The currency structure of foreign currency loans in selected economies of Central and Eastern Europe 2009 - Peter R. Haiss and Wolfgang Rainer, 2009)

The current level of Euroisation in Serbia represents a serious challenge in terms of active monetary policy, because it operates as a managed exchange rate regime because of the lack of local funding as well as because of strong foreign exchange risk and the lack of hedging instruments in mitigation of exchange rate risk, which at the same time represents the limiting factors of an active monetary policy. Since the loans are dependent on the base rate of the European Central Bank and the Swiss Sentral Bank and that there is a small percentage of loans in dinars, any change in the basic interest rate of the National Bank of Serbia has a limited effect, and questions the inflation target implemented by the National Bank of Serbia. This raises the question of monetary policy transmission channels in Serbia because of the constant depreciation of the exchange rate of RSD dinar against the euro and the high general euroisation level in Serbia. Logically, it seems that the main channel of transmission should be the exchange rate channel. However, the National Bank of Serbia trying to act onto a portfolio of economic entities, through differentiated interest rates onto dinar and foreign currency deposits, in terms of increasing the participation of dinar against euro, while indirectly trying to influence the exchange rate of both dinar and euro, followed by directing towards its goal, being a low and stable rate of inflation. It has been foreseen envisaged that such relationship between RSD and euro should be the main lever, meaning that the interest rates should reconfigure the property portfolios from euros into dinars. However, such relationship is weak, since the ratio of participation of dinar and euro has not changed significantly, but the bank lending has been decreased, which was supposed to be more intensive in dinars (Dejan Šskić, guverner Narodne banke Srbije, 2011). Such negative ratio of the property portfolio in terms of increased participation in euro and decreased participation in RSD further increased the risk premium of Serbian economy, as commercial banks reluctantly grant medium-and long-term loans in dinars due to the tendency of a strong depreciation of dinar in terms of its steady decline, which in turn leads to a reduction in 
capital inflows. Therefore, it is necessary to increase the effectiveness of monetary policy in a way to become more involved in the traditional channel of monetary policy transmission, which is the interest rate channel, and with efforts to promote the process of dinarisation by improving the functioning of the dinar money market by deepening it including the issuing of government securities denominated in dinars. Unfortunately, on $9^{\text {th }}$ February 2011, the government of the Republic of Serbia has issued securities denominated in euros by holding an auction of treasury bills denominated in euros with total value of EUR 200 million with a maturity of up to one year. The funds raised were used to finance the budget deficit and refinancing the liabilities. That was the first time that the Serbian government issued securities in euros, not in dinars. Therefore the dinarisation process was questioned. Just a few days after the emission followed a fifteen-year government issue of bonds denominated in euros. In the currency structure of government securities sold in the domestic financial market, the participation of Serbian dinar securities declined by 0.9 percentage points and amounted to $80.8 \%$, while the share of government securities denominated in euros, recorded an increase of $19.2 \%$, as shown on the following figure (National Bank of Serbia, 2011).

The currency structure of government securities of the Government of the Republic of

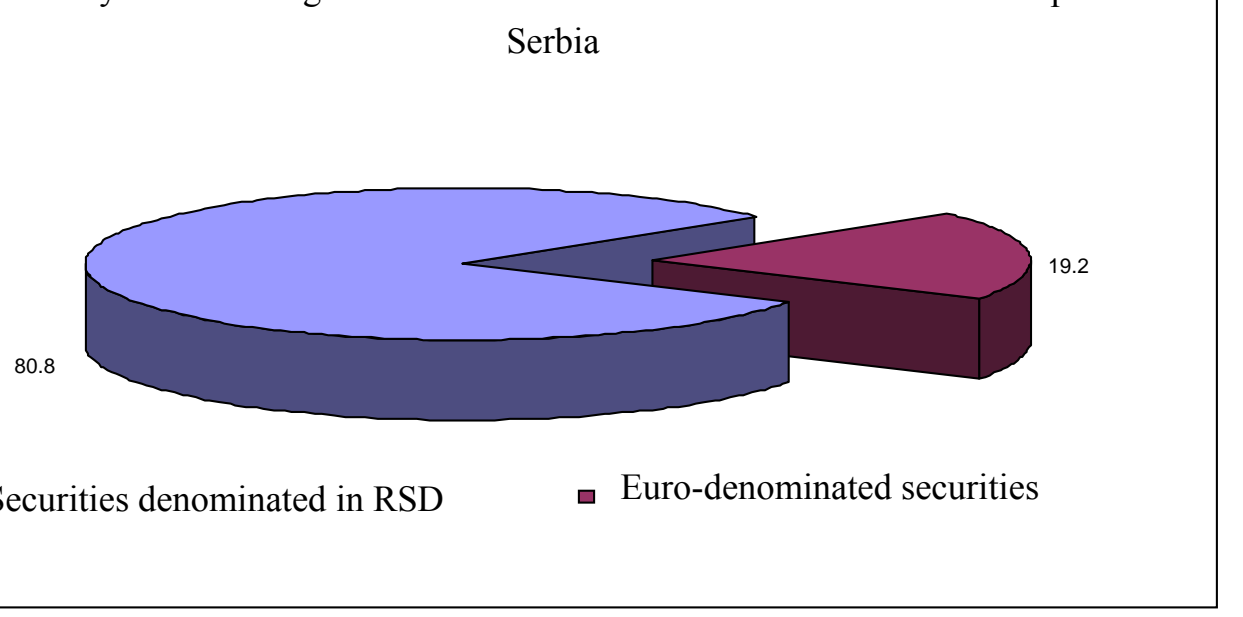

Figure 6: The Currency Structure of Government Securities $31^{\text {st }}$ December 2011

Source: National Bank of Serbia, "Report on dinarisation Serbian financial system in December 2011"

However, the total public debt of the Republic of Serbia from the aspect of currency structure is very unfavourable, because it is dominated by the share of debt denominated in euros $57 \%$ and in US $\$ 18.8 \%$, which means that any reduction in the value of the dinar exchange rate increases the level of indebtedness of the Republic of Serbia. Share of debt in dinars in total public debt, as an additional indicator for monitoring the dinarisation level of a financing system in late 2011 amounted to $14.4 \%$, and during the observed year the currency structure registered the opposite movement. In the first half of the year, this indicator also rose, from $13 \%$, as it was in late 2010 , increasing to $18.5 \%$ at the end of June 2011 . During this period, public debt grew mainly based on government indebtedness in the domestic financial market, where the debt denominated in RSD securities was twice of the debt in securities 
denominated in euros. Dinars equivalent to borrowing in euros was decreased by currency appreciation against the euro, which has further contributed to the increase in the share of dinar debt in total public debt of the Republic of Serbia. However, since the mid-2011, despite the growth of dinar portfolio of government securities, the share of debt in local currency has had a downward trend. Foreign currency debt increased by additional government borrowing in the international financial market on the sale of Eurobonds, for $\$ 1$ billion, which is why in September the share of the public debt of the Republic of Serbia in U.S. dollars was increased. In addition, the debt in euros was increased on the basis of loan guarantees to a public company Srbijagas, macroeconomic assistance of the European Union, as well as on the basis of guarantees for the loan granted by the European Investment Bank to the company Fiat. On the other hand, the reduction of debt in foreign currency was influenced by a amount of bond issues denominated in euros which was less than the amount of maturity securities indexed in euros. Certainly, the decline in the share of dinar debt in total public debt of the Republic of Serbia was resulted by a reduction of the auctions in November 2011, as well as cancellation of the planned auction of local currency securities. In November 2011, the methodology of public debt calculation on the basis of securities, so that from November, the condition of local currency and foreign currency discount securities in the state portfolio is recorded at a discount value, rather than at the nominal value. However, the greatest impact on the further reduction of the share of dinar portion of the public debt of the Republic of Serbia in November and December 2011 was additionally affected by the depreciation of dinar against euro, given that the most of the debt is denominated in euros. The following figure shows currency structure of the public debt of the Republic of Serbia in late 2011.

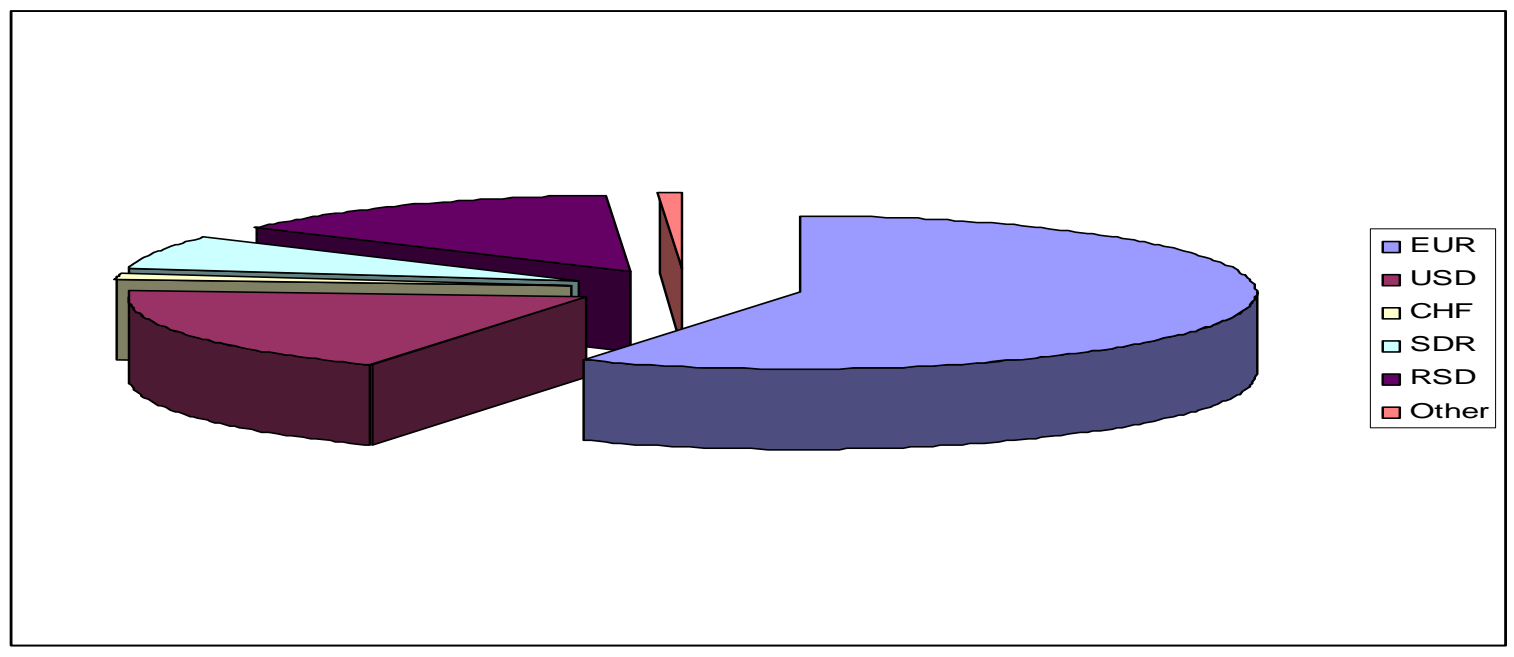

Figure 7: The currency structure of the public debt of the Republic of Serbia Source: National Bank of Serbia, "Report on dinarisation of Serbian financial system in December 2011"

When it comes to assessing the level of de facto euroisation of an economy, with the de facto euroisation meaning the use of euro and the national currency in an economy, while the de jure euroisation involving unilateral adoption of euro as legal tender, the Austrian National 
Bank provided very useful information in its research concerning the motives of holding the euro in Central and Eastern Europe and South-Eastern Europe. If the euro as currency is held primarily as a means to value it indicates that there is some degree of asset substitution, which generally indicates that there is a first step towards euroisation. If foreign currency is used as a means of payment, then it means that there is a final step towards currency substitution. In Central and Eastern Europe, the most important motif for holding the euro is for payment, while in South-Eastern Europe, the motif of keeping the euro is that the euro is used as a means to preserve the value (Sandra, Thomas \& Helmut, 2007)

\section{Costs and Benefits of Euroisation / Dollarisation}

It is clear that there are both advantages and disadvantages in the economic development of a fully dollarised economies. Salvador and other economies that have fully adopted the euro/dollar, effectively lost control over the supply of their national currency, and thus of a small part of their sovereignty in the conduct of their monetary policy (Andrew Swiston, 2011). Countries such as El Salvador, Ecuador, Panama, Montenegro, Kosovo, Andorra, San Marino sacrificed their ability to conduct countercyclical monetary interventions and rely solely on fiscal policy. Decisions on monetary policy adopted by the Federal Reserve of the United States is unlikely to take into account the troubles faced by the dollarised economy. And even if the FED took into account the macroeconomic situation in individual dollarised economies, there is no guarantee that the FED's intervention will have the same effect in El Salvador and Panama. The European Central Bank is also more prone to macroeconomic problems in the economy of Germany, France and the Benelux countries than the economies of Ireland and Portugal. In addition, dollarised economies are losing revenue from printing money as the difference between the cost of printing paper money and the purchasing power of the money created that way. Finally, in dollarised economies the Central Bank loses the position of a last resort creditor.

It has already been noted that dollarisation / euroisation is defined as the process of adopting the U.S. dollar or European euro by a country other than the United States or the euro area as a legal tender and official currency, with the result that the country decides to abandon its own currency and its own Central Bank, or to give up the instruments of monetary policy pursued by its Central Bank. In fact there is a very widespread opinion about the important benefits and costs of full dollarisation / euroisation, which can be grouped as follows (Nikola Fabris, 2007). The following advantages are considered as the most important (Winkler, Adalbert, Mazzaferro, Francesco, Nerlich, Carolin \& Thimann, Christian, 2004): (1) Macro-economic stability is promoted. Dollarisation / euroisation enhances macroeconomic stability by resolving the problem of credibility that arises when a domestic central bank is unable to meet its goal, i.e. a low and stable rate of inflation. Dollarisation / Euroisation adopts the monetary policy of a country which has a high degree of credibility in maintaining low and stable inflation. Credibility is enhanced in the simplest way, by improving fiscal discipline of a country that is dolarised / euroised, because there is no possibility of printing money to finance the state budget deficit. (2) Investment risk premium is reduced. The risk 
premium caused by the devaluation of the local currency, but not due to the state risk, should be lead to lower investment risk premium by the dollarisation / euroisation due to the sudden and sharp devaluation of the local currency in comparison to the currency that represents some sort of a reference anchor. Specifically if the country is faced with borrowing in foreign currency by the public or private sector and the absence of revenue flows from exports, dollarisation / euroisation eliminates this problem by reducing the sovereign risk of a country under the assumption that the international capital market is functioning well. As a result, the access of a country to international capital markets is improved. (3) Development of the domestic financial sector. Stable currency with dollarisation / euroisation is a precondition of the development of the financial sector followed by a strong and stable economic growth, (4) Transaction cost is eliminated. Specifically, the cost of exchanging the local currency into a currency that is a reference anchor (the Euro and the U.S. dollar) is eliminated. The savings are equal to the number of transactions that are carried out in a foreign currency. (5) Economic and financial integration is strengthened. Since dollarisation / euroisation is expected to stimulate economic integration of a country with the economy of the country that issues the reserve currency. In particular, the elimination of exchange rate risk on the assumption that the trade is liberalized strengthens the economic and financial integration.

The disadvantages are: (1) Loss od adjustment mechanism. In the process of full dollarisation / euroisation, an economy loses the ability to use monetary policy to adjust the economy to asymmetric shocks and to react to changes in the business cycle. Only the possibility of fiscal response is what remains. (2) Loss of a creditor as the last resort. Domestic monetary authorities lose the ability to be a last resort creditor because they do not print their own currency. (3) The most direct cost is the loss of seigniorage. Full dollarisation / euroisation eliminates seigniorage to a domestic Central Bank because it loses its function of issuing domestic currency.

Thus, in small countries, developing countries, there are many reasons to conduct a complete dollarisation / euroisation: (1) firstly, the exchange rate risk is thereby eliminated. This means that there is no exchange rate nor the possibility of depreciation of the national currency and on that basis there is no outflow of capital due to the fear of loss of value of the local national currency, (2) Use of the dollar or the euro, can substantially assist the country to integrate into the global market, increasing their relative share in world trade and investment, (3) Possibility of inflationary financing is eliminated. That way, the country can reduce the premium due to the high system risk. The premium has to be paid for loans due to the high political risk and thus the country must generally strengthen its financial institutions. This means that in this case the euros and dollars are in the hands of their central banks. The dollar and the euro must be reached only by strengthening foreign trade.

Benefits of Euroisation / dollarisation are balancing against the loss of income resulting from the issuance of money, which is known as seignorage. Printing money is very cheap. When a country decides to accept foreign currency, or to forcibly bind itself to a monetary system, the profit of the money issuance belongs to the country which the minor country is bonded to. In the cases of Ecuador, Montenegro, Monaco, Panama, Kosovo, seignorage belongs to the U.S. and to the ECB. In addition, the process of euroisation / dollarisation effectively eliminates 
$\mathrm{CB}$ function as a last resort creditor, because, for example, the euro is printed by ECB and the dollar is printed by FED, not the Central Bank of Ecuador, or Serbia. If the banking system falls into a crisis, the government must find a way to provide the necessary liquidity. In Argentina, this problem was solved by having the Argentine banks borrowing funds from large U.S. commercial banks. Third, the economies that have been completely dollarised / euroised, lost their independence in the management of foreign exchange and monetary policy. However, since foreign investors had no confidence in the monetary authorities of the economies that have adopted the euro and the dollar, and that the monetary authorities had created the crisis of enormous proportions, this loss can hardly be considered as a serious loss, because the benefits are far greater. Accepting the foreign currency has more benefits than disadvantages even though such decision is very sensitive, especially due to political reasons but also for economic reasons, such as in Mexico and Canada. Also, there must be a clear distinction between the euroisation / dollarisation and a monetary union. The decision of the European countries to adopt a common currency, the euro, is fundamentally different from the decisions of individual countries to adopt the euro or the U.S. dollar as their currency to be legal tender. When the U.S. FED i.e. FOMC reaches a decision, it applies to Ecuador, El Salvador and Panama as well. In contrast, all European countries are members of the Economic and Monetary Union, and accept the Monetary decisions and jointly participate in the revenue that comes from printing money. European Central Bank continues to function as a last resort creditor by approving loans in euros to its commercial banks. Monetary union, unlike Euroisation, represents a joint managing monetary policy, while a dollarisation is not a common monetary policy management.

\section{Macroeconomic Effects of the Unofficial Euroisation in Serbia}

The aim of this study was to establish the effects of informal Euroisation in Serbia onto a general rise in prices, or the inflation and the growth of GDP and their mutual influences. We used standard statistical methods with the following markings,

kv1CENEm (q1PRICESm) - Calculated quarterly value for the price change on a monthly basis; arithmetic mean was used for three months making the quarter

KV1EVRO (q1EURO)- euro value in the quarter; the same procedure was used, i.e. a mean rate for the three months constituting the quarter was used for the value of the euro in the quarter

BDP rast (GDP growth) - the marking representing a BDP rast by quarter

The study focused on 22 quarters. The first quarter observed being the I quarter 2007, with the last, observed quarter was II quarter of 2012; all the data has been downloaded from the National Bank of Serbia website.

Firstly, the data has been grouped in the following figure 


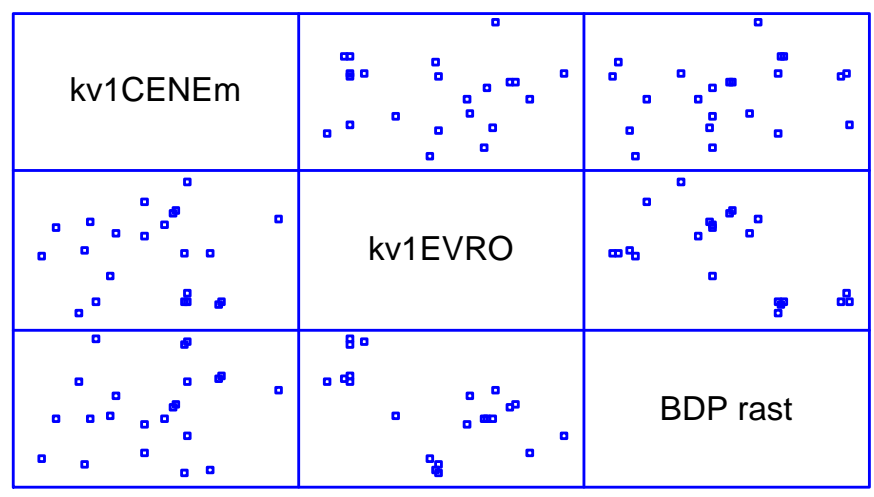

Figure 8: Computed by the Authors

Followed by the calculation of the correlation between the observed variables

Table 6: Correlations

\begin{tabular}{llll}
\hline & kv1CENEm & kv1EVRO & BDP rast \\
\hline kv1CENEm & & 0.0114 & 0.2054 \\
& & $(22)$ & $(22)$ \\
\multirow{4}{*}{ kv1EVRO } & 0.0114 & 0.9599 & 0.3591 \\
& $(22)$ & & -0.5742 \\
& 0.9599 & & $(22)$ \\
BDP rast & 0.2054 & -0.5742 & 0.0052 \\
& $(22)$ & $(22)$ & \\
& 0.3591 & 0.0052 & \\
\hline
\end{tabular}

Calculated by the Authors

This table shows Pearson product moment correlations between each pair of variables. These correlation coefficients range between -1 and +1 and measure the strength of the linear relationship between the variables. Also shown in parentheses is the number of pairs of data values used to compute each coefficient. The third number in each location of the table is a P-value which tests the statistical significance of the estimated correlations. P-values below 0.05 indicate statistically significant non-zero correlations at the $95.0 \%$ confidence level. The following pairs of variables have P-values below 0.05 :

Based on the above analysis we can conclude that there is a negative link between the exchange rate and GDP. With the rise of the euro exchange rate, a GDP has been falling. There is no dependency between inflation and the euro exchange rate, as well as between inflation and GDP.

Below there are a few analyzes that confirm the previous conclusion. Only the analysis that follows are somewhat more sophisticated. For example, the correlation with lags was also observed. For the analysis of GDP and euro relationship, a linear and a quadratic model was used. 
Simple Regression - BDP rast vs. kv1EVRO

Dependent variable: BDP rast

Independent variable: kv1EVRO

Linear model: $\mathrm{Y}=\mathrm{a}+\mathrm{b} * \mathrm{X}$

Table 7: Coefficients

\begin{tabular}{|c|c|c|c|c|}
\hline & Least Squares & Standard & $T$ & \\
\hline Parameter & Estimate & Error & Statistic & P-Value \\
\hline Intercept & 17.6895 & 5.22532 & 3.38535 & 0.0029 \\
\hline Slope & -0.172918 & 0.0551323 & -3.13641 & 0.0052 \\
\hline
\end{tabular}

Calculated by the Authors

Table 8: Analysis of Variance

\begin{tabular}{llllll}
\hline Source & $\begin{array}{l}\text { Sum of } \\
\text { Squares }\end{array}$ & Df & $\begin{array}{l}\text { Mean } \\
\text { Square }\end{array}$ & F-Ratio & P-Value \\
\hline Model & 82.233 & 1 & 82.233 & 9.84 & 0.0052 \\
Residual & 167.19 & 20 & 8.35951 & & \\
Total (Corr.) & 249.423 & 21 & & & \\
\hline
\end{tabular}

Calculated by the Authors

Correlation Coefficient $=-0.574189$

$\mathrm{R}$-squared $=32.9693$ percent

R-squared (adjusted for d.f.) $=29.6177$ percent

Standard Error of Est. $=2.89128$

Mean absolute error $=2.16771$

Durbin-Watson statistic $=0.504914(\mathrm{P}=0.0000)$

Lag 1 residual autocorrelation $=0.705733$ 


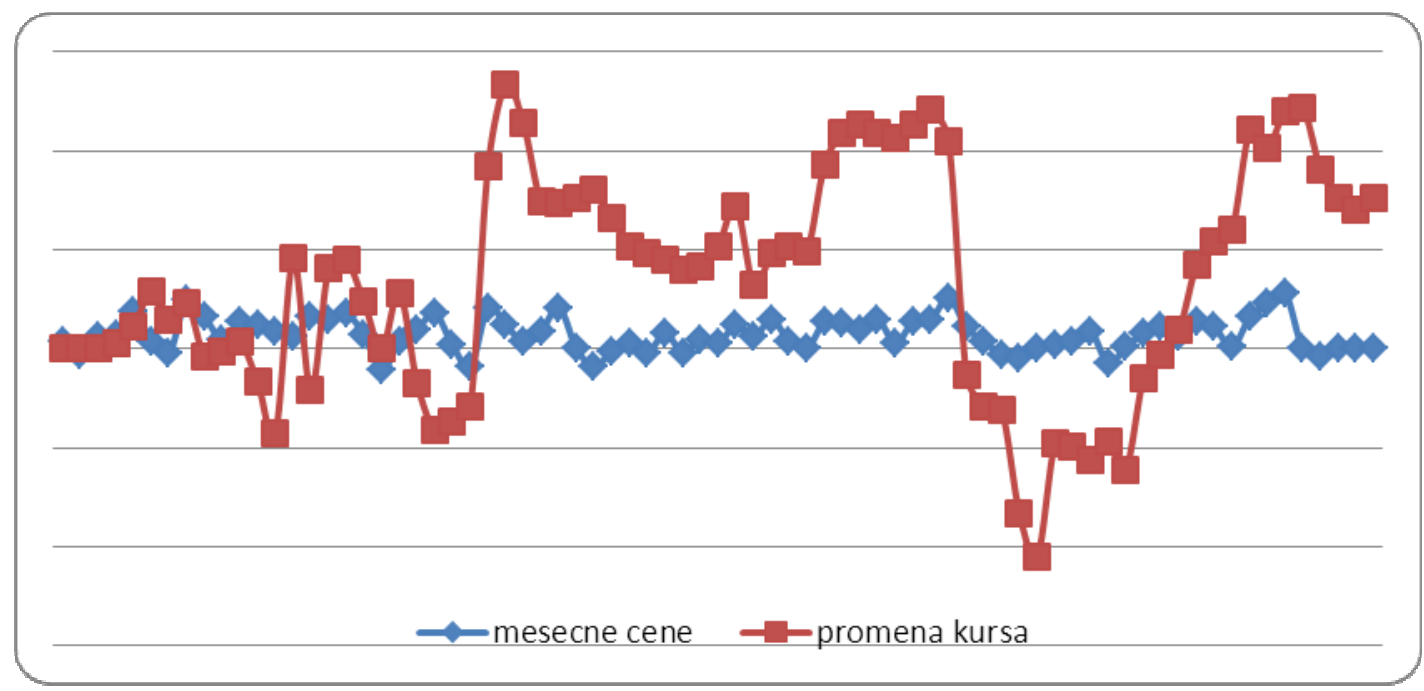

Figure 9: Mesecne cene (monthly prices) promena kursa (exchange rate modification)

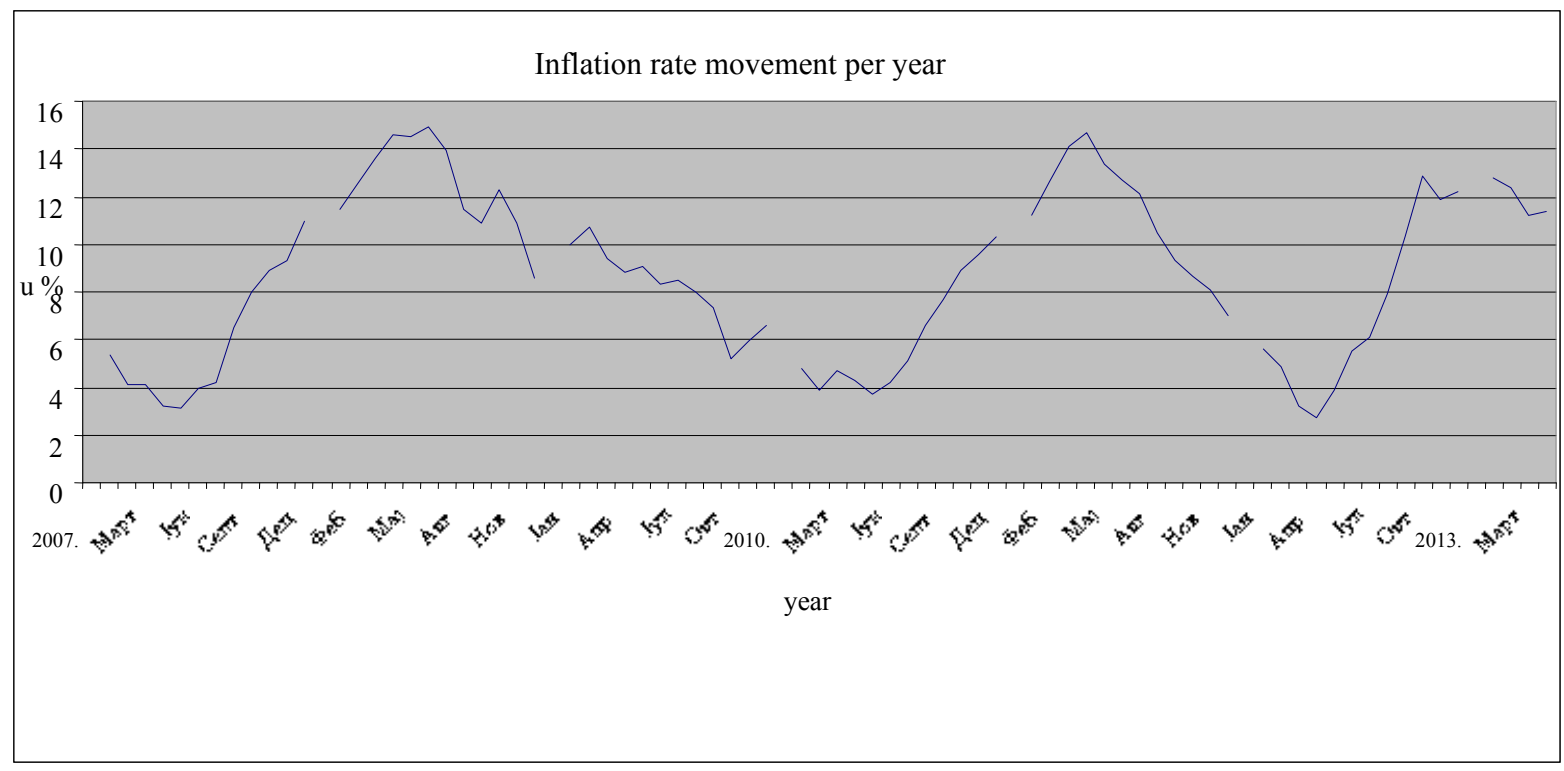

Figure 10: Inflation rate movement - Official Statement of NBS

From the chart it can be clearly seen that in the period from 2007 to the first quarter of 2013, the inflation rate was high and very unstable, ranging from 5\% to almost $14.2 \%$.

\section{Relationship between Prices and Exchange Rates}

The study focused on characteristics of the monthly price changes and monthly exchange rate changes. It is expected that the prices respond to exchange rate change with a certain time lag. The correlation coefficients were observed for monthly price changes and exchange rate changes without a time lag, with one, two, three, four and five months. Statistically significant coefficient, i.e. price reaction to the exchange rate change, is obtained for a three-month delay. That is, the results obtained show that the impact of exchange rate 
fluctuations is the strongest after three months. Figure 1 figureically shows the series of price changes and exchange rate changes with a three-month delay. However, it should be noted that in this case the dependency is not strong, and that the change in the exchange rate can help to explain a relatively small portion of the change in prices.

Table 9: Correlation of variation of general price level and exchange rate

\begin{tabular}{|c|c|c|c|c|c|c|c|}
\hline & \multicolumn{6}{|c|}{ Change } \\
\hline & & $\mathrm{p}(\mathrm{t})$ & $\mathrm{p}(\mathrm{t}-1)$ & $p(t-2)$ & $p(t-3)$ & $p(t-4)$ & $\mathrm{p}(\mathrm{t}-5)$ \\
\hline \multirow{3}{*}{$\begin{array}{l}\text { Monthly } \\
\operatorname{prices}(\mathrm{t})\end{array}$} & $\begin{array}{l}\text { Pearson } \\
\text { Correlation }\end{array}$ & .136 & .147 & .224 & $.326^{* *}$ & .227 & .164 \\
\hline & Sig. (2-tailed) & .255 & .221 & .062 & .006 & .063 & .184 \\
\hline & $\mathrm{N}$ & 72 & 71 & 70 & 69 & 68 & 67 \\
\hline
\end{tabular}

Calculated by the Authors

\section{Relationship between the Price and GDP in Serbia}

In this case, there is a problem because the data provided were not for the same time periods, meaning that the GDP is presented on a quarterly basis, while the exchange rate is presented on a monthly basis. For comparison, the monthly data are converted into quarterly by the observed mean rate in each quarter. Note: The validity of such data translation is not a matter of statistics, but of expertise. In this case, the dependence of GDP growth on the exchange rate change has been analysed. The delays of 0,1,2,3,4 quarter have been observed. Table 2 shows the values of correlation coefficients with a suitable test. It can be concluded that an apparent correlation between the exchange rate and GDP has not been noted. Such finding may be due to the relatively short series of time $(\mathrm{N}=18)$.

Table 10: Correlation of economic growth and GDP in Serbia

\begin{tabular}{llccccc}
\hline & & \multicolumn{5}{c}{ Growth } \\
\cline { 3 - 7 } & & $\mathrm{BDP}(\mathrm{t})$ & $\mathrm{BDP}(\mathrm{t}-1)$ & $\mathrm{BDP}(\mathrm{t}-2)$ & $\mathrm{BDP}(\mathrm{t}-3)$ & $\mathrm{BDP}(\mathrm{t}-4)$ \\
\hline \multirow{3}{*}{$\begin{array}{l}\text { Exchange rate } \\
\text { growth (t) }\end{array}$} & $\begin{array}{l}\text { Cearson } \\
\text { Correlation }\end{array}$ & -0.3332 & -0.3456 & -0.3352 & -0.1699 & -0.1784 \\
& Sig. (2-tailed) & 0.1767 & 0.1602 & 0.1738 & 0.5004 & 0.4787 \\
& $\mathrm{~N}$ & 18 & 18 & 18 & 18 & 18 \\
\hline
\end{tabular}

Calculated by the Authors

The output shows the results of fitting a linear model to describe the relationship between $\mathrm{BDP}$ rast and kv1EVRO. The equation of the fitted model is

$$
\text { BDP rast }=17.6895-0.172918 * \mathrm{kv} 1 \mathrm{EVRO}
$$

Since the P-value in the ANOVA table is less than 0.05, there is a statistically significant relationship between BDP rast and kv1EVRO at the $95.0 \%$ confidence level.

The R-Squared statistic indicates that the model as fitted explains $32.9693 \%$ of the variability 


\section{Macrothink}

Research in Applied Economics

ISSN 1948-5433

2013, Vol. 5, No. 4

in BDP rast. The correlation coefficient equals -0.574189 , indicating a moderately strong relationship between the variables. The standard error of the estimate shows the standard deviation of the residuals to be 2.89128 . This value can be used to construct prediction limits for new observations by selecting the Forecasts option from the text menu.

The mean absolute error (MAE) of 2.16771 is the average value of the residuals. The Durbin-Watson (DW) statistic tests the residuals to determine if there is any significant correlation based on the order in which they occur in your data file. Since the P-value is less than 0.05 , there is an indication of possible serial correlation at the $95.0 \%$ confidence level. Plot the residuals versus row order to see if there is any pattern that can be seen.

Plot of Fitted Model

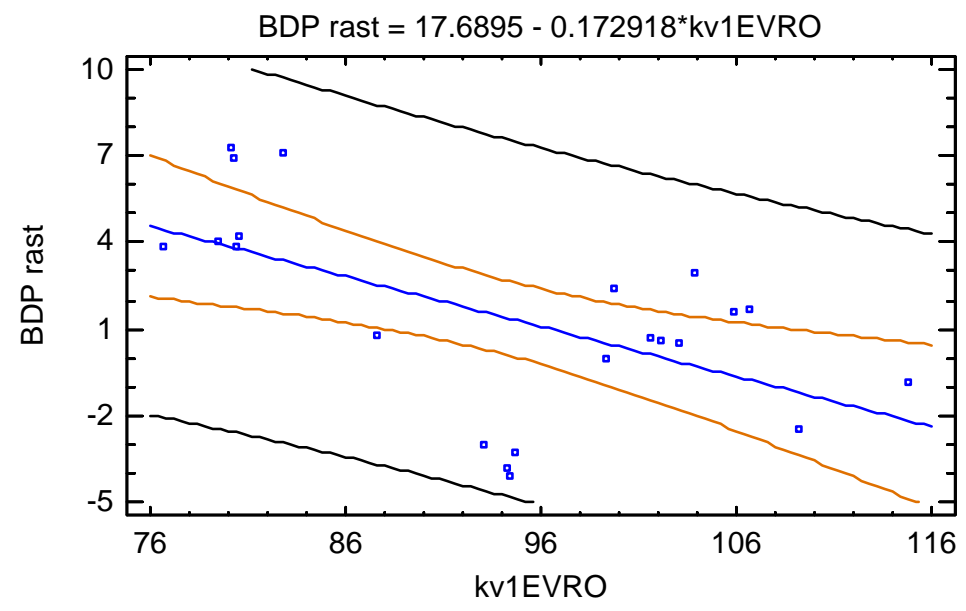

Figure 11: Dependence of depreciation of the Dinar exchange rate of the RSD to GDP

Residual Plot

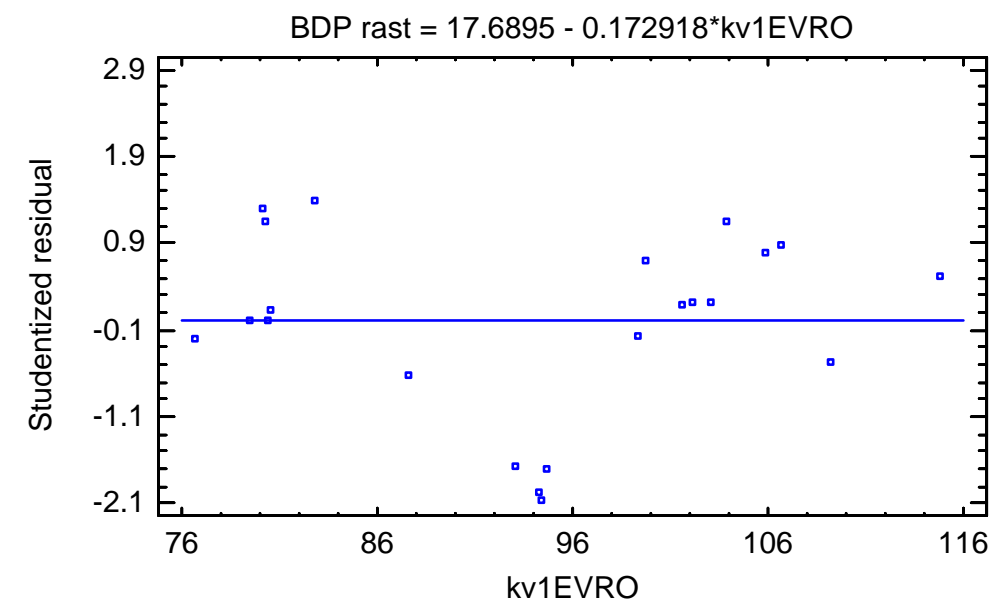

Figure 12: Statistical Deviation and Measurement of Standard Error

Polynomial Regression - BDP rast versus kv1EVRO

Dependent variable: BDP rast

Independent variable: kv1EVRO

Order of polynomial $=2$ 
Table 11: Calculation of Expected Values

\begin{tabular}{|c|c|c|c|c|}
\hline & & Standard & $T$ & \\
\hline Parameter & Estimate & Error & Statistic & P-Value \\
\hline CONSTANT & 119.787 & 45.1974 & 2.6503 & 0.0158 \\
\hline kv1EVRO & -2.38183 & 0.97373 & -2.44609 & 0.0243 \\
\hline $\mathrm{kv} 1 \mathrm{EVRO}^{\wedge} 2$ & 0.0117776 & 0.00518492 & 2.27152 & 0.0349 \\
\hline
\end{tabular}

Calculated by the Authors

Table 12: Analysis of Variance

\begin{tabular}{llllll}
\hline Source & $\begin{array}{l}\text { Sum of } \\
\text { Squares }\end{array}$ & Df & $\begin{array}{l}\text { Mean } \\
\text { Square }\end{array}$ & F-Ratio & P-Value \\
\hline Model & 117.94 & 2 & 58.9699 & 8.52 & 0.0023 \\
Residual & 131.483 & 19 & 6.92018 & & \\
Total & 249.423 & 21 & & & \\
(Corr.) & & & & & \\
\hline
\end{tabular}

Calculated by the Authors

R-squared $=47.285$ percent

R-squared (adjusted for d.f.) $=41.7361$ percent

Standard Error of Est. $=2.63062$

Mean absolute error $=2.16278$

Durbin-Watson statistic $=0.758041(\mathrm{P}=0.0001)$

Lag 1 residual autocorrelation $=0.570034$

\section{The StatAdvisor}

The output shows the results of fitting a second order polynomial model to describe the relationship between BDP rast and kv1EVRO. The equation of the fitted model is

$\mathrm{BDP}$ rast $=119.787-2.38183 * \mathrm{kv} 1 \mathrm{EVRO}+0.0117776 * \mathrm{kv}^{\mathrm{E}} \mathrm{EVRO}^{\wedge} 2$

Since the P-value in the ANOVA table is less than 0.05, there is a statistically significant relationship between BDP rast and kv1EVRO at the 95\% confidence level.

The R-Squared statistic indicates that the model as fitted explains $47.285 \%$ of the variability in BDP rast. The adjusted R-squared statistic, which is more suitable for comparing models with different numbers of independent variables, is $41.7361 \%$. The standard error of the estimate shows the standard deviation of the residuals to be 2.63062. This value can be used to construct prediction limits for new observations by selecting the Forecasts option from the text menu. The mean absolute error (MAE) of 2.16278 is the average value of the residuals. The Durbin-Watson (DW) statistic tests the residuals to determine if there is any significant correlation based on the order in which they occur in your data file. Since the P-value is less 
than 0.05 , there is an indication of possible serial correlation at the $95 \%$ confidence level. Plot the residuals versus row order to see if there is any pattern that can be seen.

In determining whether the order of the polynomial is appropriate, note first that the P-value on the highest order term of the polynomial equals 0.0349287. Since the P-value is less than 0.05 , the highest order term is statistically significant at the $95 \%$ confidence level. Consequently, you probably don't want to consider any model of lower order.

Plot of Fitted Model

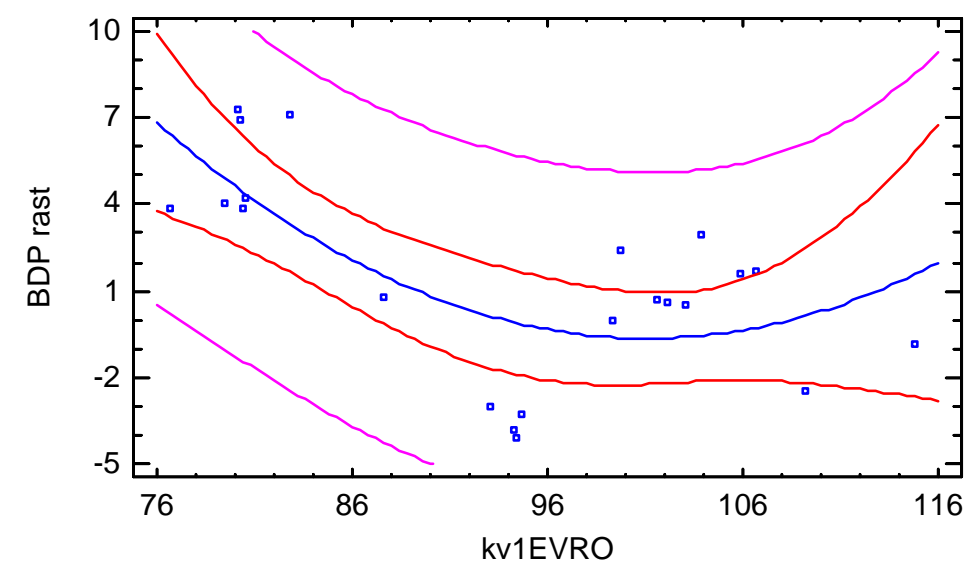

Figure 13: Statistical relation between GDP and exchange rate

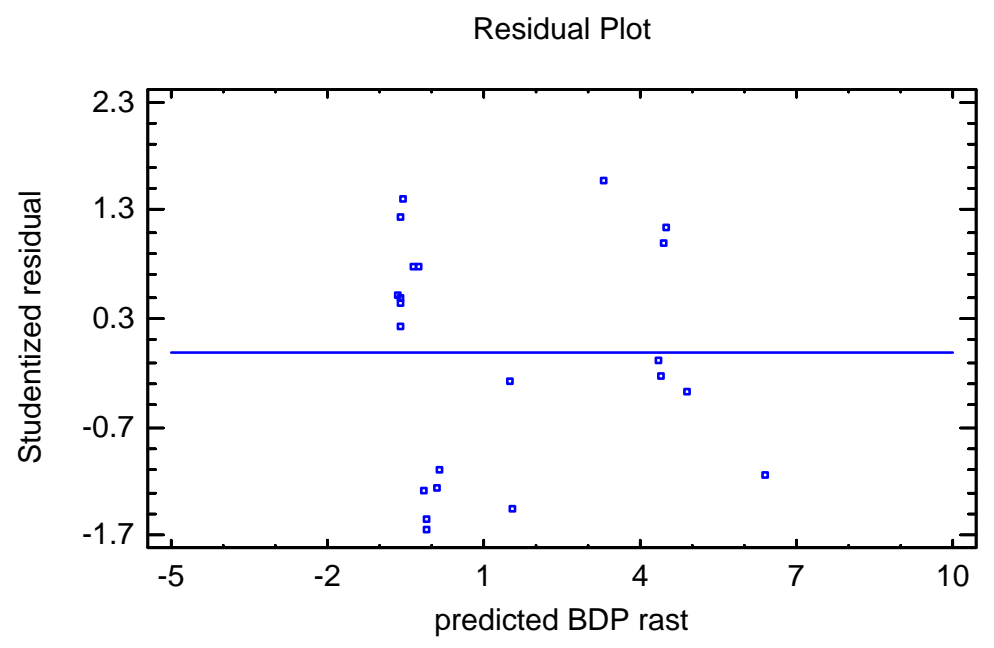

Figure 14: Statistical deviations and measurement of standard error

Descriptive Methods - kv1CENEm

Data variable: kv1CENEm

Number of observations $=22$

Start index $=\mathrm{Q} 1 / 50$

Sampling interval $=1.0$ 
The StatAdvisor

This procedure constructs various statistics and plots for kv1CENEm. The data cover 22 time periods. Select the desired tables and figures using the buttons on the analysis toolbar.

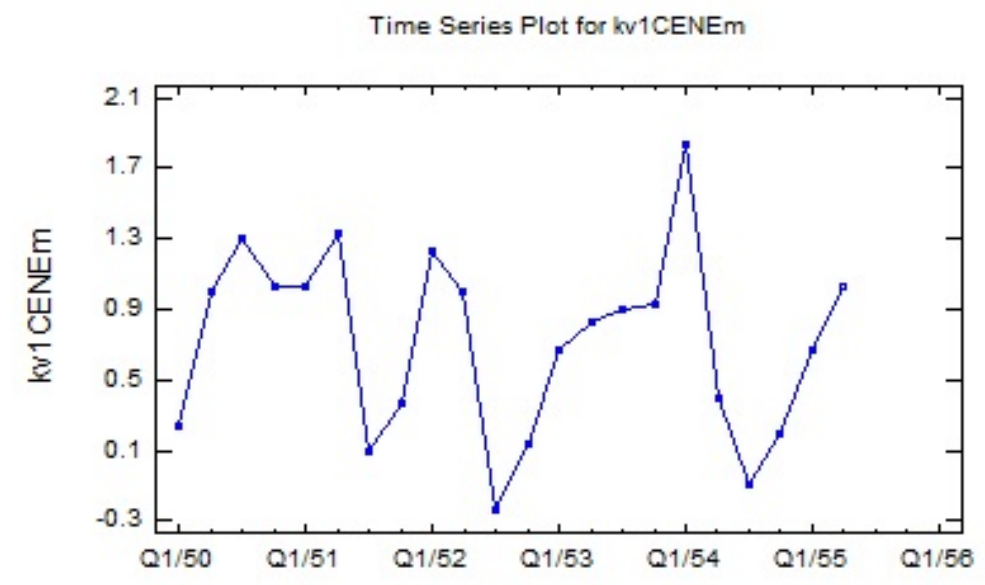

Figure 15: Price movement - Official data of NBS

Table 11: Estimated Autocorrelations for kv1CENEm

\begin{tabular}{lllll}
\hline & & & Lower 95.0\% & Upper 95.0\% \\
Lag & Autocorrelation & Stnd. Error & Prob. Limit & Prob. Limit \\
\hline 1 & 0.216306 & 0.213201 & -0.417867 & 0.417867 \\
2 & -0.350777 & 0.222953 & -0.436981 & 0.436981 \\
3 & -0.172544 & 0.246767 & -0.483655 & 0.483655 \\
4 & -0.0219752 & 0.252191 & -0.494286 & 0.494286 \\
5 & -0.208665 & 0.252278 & -0.494457 & 0.494457 \\
6 & -0.129711 & 0.260005 & -0.509601 & 0.509601 \\
7 & 0.192292 & 0.26293 & -0.515334 & 0.515334 \\
\hline
\end{tabular}

Calculated by the Authors

The StatAdvisor

This table shows the estimated autocorrelations between values of kv1CENEm at various lags. The lag $\mathrm{k}$ autocorrelation coefficient measures the correlation between values of kv1CENEm at time $\mathrm{t}$ and time $\mathrm{t}-\mathrm{k}$. Also shown are $95.0 \%$ probability limits around 0 . If the probability limits at a particular lag do not contain the estimated coefficient, there is a statistically significant correlation at that lag at the $95.0 \%$ confidence level. In this case, none of the 24 autocorrelations coefficients are statistically significant, implying that the time series may well be completely random (white noise). You can plot the autocorrelation coefficients by selecting Autocorrelation Function from the list of Numerical Options. 


\section{Macrothink}

Table 12: Estimated Crosscorrelations for kv1CENEm with kv1EVRO

\begin{tabular}{ll}
\hline Lag & Crosscorrelation \\
\hline-7 & 0.0116604 \\
-6 & 0.0425505 \\
-5 & 0.104345 \\
-4 & -0.0796228 \\
-3 & -0.263943 \\
-2 & -0.325023 \\
-1 & -0.243573 \\
0 & 0.0113924 \\
1 & -0.0389249 \\
2 & -0.168426 \\
3 & -0.141499 \\
4 & 0.00286877 \\
5 & 0.0575073 \\
6 & 0.118022 \\
7 & 0.0950962 \\
\hline
\end{tabular}

Calculated by the Authors

The StatAdvisor

This table shows cross-correlations between kv1CENEm and kv1EVRO. The cross-correlation at lag $\mathrm{k}$ measures the strength of the linear relationship between the value of kv1CENEm at time $\mathrm{t}$ and the value of kv1EVRO $\mathrm{k}$ periods earlier. It can be used to determine whether kv1EVRO would help forecast kv1CENEm.

Table 13: Estimated for kv1CENEm with BDPrast

\begin{tabular}{ll}
\hline Lag & Crosscorrelation \\
\hline-7 & -0.218791 \\
-6 & -0.322116 \\
-5 & -0.227467 \\
-4 & -0.170733 \\
-3 & 0.116762 \\
-2 & 0.306945 \\
-1 & 0.309552 \\
0 & 0.205399 \\
1 & 0.30154 \\
2 & 0.252002 \\
3 & 0.101529 \\
4 & 0.025755 \\
5 & -0.215451 \\
6 & -0.386648 \\
7 & -0.139814 \\
\hline
\end{tabular}


Calculated by the Authors

The StatAdvisor

This table shows cross-correlations between kv1CENEm and BDP rast. The cross-correlation at lag $\mathrm{k}$ measures the strength of the linear relationship between the value of kv1CENEm at time $t$ and the value of BDP rast $k$ periods earlier. It can be used to determine whether BDP rast would help forecast kv1CENEm.

\section{Conclusion}

Unofficial euroisation has been accomplished in Serbia by introducing the European euro, causing the European euro to become a medium of exchange, billing unit, value, and standard of deferred payment, even though the official currency of Serbia is a Serbian dinar. Unofficial euroisation aimed at stabilizing the value of the Serbian dinar and stabilizing the Serbian economy. In other words, informal euroisation should have improved macroeconomic performance of the Serbian economy. However, the opposite happened: unofficial euroisation firstly reduced the powers of the National Bank of Serbia with regards to the management of monetary policy and caused the Serbian economy to be heavily exposed to the risk of exchange rate fluctuations during the global recession and financial crisis since 2007. Depreciation of the Serbian dinar additionally decreased the already declining confidence in the national currency and increased the level of unofficial euroisation and inflation in Serbia. Inflation in Serbia is moderately high, the highest in the region. Likewise, the unofficial euroisation influenced the positive correlation in the movement of the Serbias GDP and the Serbian exchange rate. As the exchange rate depreciated, the gross domestic product decreased and vice versa. A general conclusion is that the negative effects of the unofficial euroisation in Serbia were much more present than the positive effects, which means that the unofficial euroisation had a positive effect on stabilizing the Serbian economy in the short term, but Serbia's economy is facing a period of deep structural changes, in particular the reform of the public sector in terms of reducing public expenditure, reducing the budget deficit, and adherence to fiscal consolidation and strengthening of export potential, in order to thereby improve macroeconomic performance. The unofficial euroisation may cause more negative effects than positive effects.

The goal of research is to prove that the borrowing the credibility of the euro does not have a substantially positive influence onto the Serbian economy, but that numerous structural reforms expect Serbia in order to restore and retain the trust in the domestic currency

\section{Acknowledgement and Sponsoring information}

Faculty of Economics in Subotica, University of Novi Sad;

Faculty of Business Economics in Bijeljina, University of East Sarajevo 


\section{References}

Alexandre Minda. (2005). Full Dollarization: A Last Resort Solution to Financial Instability in Emerging Countries? The European Journal of Development Research, 17(2), 289-316. http://dx.doi.org/10.1080/09578810500131011

Andrew Swiston. (2011). Official Dollarization as a Monetary Regime: Its Effects on El Salvador, IMF Working Paper, WP/11/129 http://dx.doi.org/10.1353/mcb.2006.0016

Anne-Marie Gulde, David Hoelscher, Alain Ize, David Marston, \& Gianni De Nicoló. (2004). Financial Stability in Dollarized Economies, International Monetary Fund, Washington DC. Retrieved from http://www.imf.org/external/pubs/cat/longres.aspx?sk=16918

David S. Bloch, \& William Robert Nelson Jr. (2003). Dollarization in El Salvador: The Costs of Economic Stability. Latin American Law \& Business Report, 11(4), 1-3. http://winston.com/siteFiles/publications/BlochLatinAmBusReport04-03.pdf

Dejan Šoškić, governor of the National Bank of Serbia, (2011). Current macroeconomic developments - $\quad$ December $2011^{\text {th }} \quad$ Belgrade. http://www.nbs.rs/internet/english/15/konferencije_guvernera/attachment/20111114_DS presentation.pdf

Yeyati, E. L. (2006). Financial dollarization: evaluating the consequences. Economic Policy, 21, 61-118. http://dx.doi.org/10.1111/j.1468-0327.2006.00154.x

Feige, Edgar L., \& James W. Dean. (2004). Dollarization and euroisation in Transition Countries: Currency Substitution, Asset Substitution, Network Externalities, and Irreversibility in Monetary Unions and Hard Pegs, Volbert Alexander, Jacques Mélitz, and George M. von Furstenberg (eds.), New York: Oxford University Press:, pp. 303-321. http://128.118.178.162/eps/if/papers/0205/0205003.pdf

Fischer, S. (2001). Exchange Rate Regimes: Is the Bipolar View Correct? Finance \& Development, a quarterly magazin of the IMF, 38(2), Retrieved from http://www.imf.org/external/np/speeches/2001/010601a.htm

Gianni De Nicoló, Patrick Honohan, \& Alain Ize. (2003). Dollarization of the Banking System: Good or Bad? World Bank Policy Research Working Paper 3116. http://dx.doi.org/10.1596/1813-9450-3116

IMF (2001). Federal Republic of Yugoslavia: Membership and Request for Emergency Postconflict Assistance, IMF Staff Country Report No. 01/07, Washington, DC. http://www.imf.org/external/pubs/ft/scr/2001/cr0107.pdf

Jose Luis Cordeiro. (2002). Different Monetary Systems: Costs and Benefits to Whom? Hispanic American Center for Economic Research. Retrieved from http://www.sicht.ucv.ve:8080/bvirtual/doc/analisis\%20de\%20coyuntura/contenido/volu menes/2003/1/04-Cordeiro.pdf

Juan Luis Moreno-Villalaz. (2005). Financial Integration and Dollarization: The Case Of 
Panama Cato Journal,

$25(1)$

127-140.

http://www.cato.org/sites/cato.org/files/serials/files/cato-journal/2005/1/cj25n1-14.pdf

Klauser, P. (2001). Legal Implications of Currency Boards, 2002. “Dollarization” and Similar Arrangements - A Bilateral Monetary Treaty: Switzerland - Liechtenstein, Paper presented at the BIS/CEMLA/MOCOMILA seminar, Mexico City, http://www.ecb.europa.eu/pub/pdf/scpops/ecbocp11.pdf

Marijana Ivanov, Marina Tkalec \& Maruška Vizek. (2011). The Determinants of Financial Euroization in a Post-Transition Country: Do Threshold Effects Matter? Czech Journal of Economics and Finance, 61(3), 230-251. http://journal.fsv.cuni.cz/storage/1213_vizek.pdf

Meade, Ellen E., Müller-Plantenberg, Nikolas \& Pisani, Massimiliano. (2002). Exchange rate arrangements in EU accession countries: what are the options? Centre for Economic Performance Occasional Papers, CEPOP 17. Centre for Economic Performance, London School of Economics and Political Science, London, UK. http://eprints.lse.ac.uk/28754/

National Bank Of Serbia (2011). December report on dinarisation of Serbian financial system. http://www.nbs.rs/static/nbs_site/gen/latinica/90/dinarizacija/din_12_12.pdf

Nikola Fabris. (2007). Euroisation in Montenegro - advantages, disadvantages and limitations. Quarterly monitor of economic trends and policies in Serbia, 11, Belgrade, 87-94. http://www.fren.org.rs/sites/default/files/qm/qm11-00-complete.pdf

Panama. (2011). Article IV consultation, IMF Country report no. 12/83 http://www.imf.org/external/pubs/ft/scr/2012/cr1283.pdf

Peter R. Haiss \& Wolfgang Rainer. (2011). Credit Euroization in CESEE: The "Foreign Funds" Channel at Work. $17^{\text {th }}$ Dubrovnik Economic Conference organized by the Croatian National Bank. Retrieved from http://www.hnb.hr/dub-konf/17-konferencija/haiss-rainer3.pdf

Petrakos, G. (2001). Fragmentation or Integration in the Balkans? Strategies of Development for the 21st Century. In G. Petrakos and S. Totev (Eds) The Development of the Balkan Region. (pp. 219-234).Ashgate: London,

Piritta Sorsa. (2006). Macroeconomic Challenges with EU Accession in SE Europe: An Overview IMF Working Paper WP/06/40http://www.imf.org/external/pubs/ft/wp/2006/wp0640.pdf

Poul M. Thomsen \& Michele Shannon. (2010). Republic of Serbia: Staff Report for the 2010 Article IV Consultation, Third Review Under the Stand-By Arrangement, and Financing $\begin{array}{llllll}\text { Assurances Review, IMF Country Report No. 10/93 } & \end{array}$ http://www.imf.org/external/pubs/ft/scr/2010/cr1093.pdf

International Monetary Fund. (2010). Republic of Serbia: Financial Sector Assessment Program Update-Technical Note on Systemic Liquidity Management. The World Bank. Retrieved from http://www.imf.org/external/pubs/ft/scr/2010/cr10153.pdf 


\section{Macrothink}

Sandra Dvorsky, Thomas Scheiber \& Helmut Stix. (2008). Euroization in Central, Eastern and Southeastern Europe - First Results from the New OeNB Euro Survey, Focus On European Economic Integration 1/08 Retrieved from http://www.oenb.at/en/img/feei_2008_1_dvorsky_tcm16-86774.pdf

Sebastian Edwards. (2001). Dollarization and Economic Performance: An empirical Investigation, NBER Working Paper Series, National Bureau of Economic Research, Cambridge, pp. 6-12. http://www.nber.org/papers/w8274

Winkler, Adalbert, Mazzaferro, Francesco, Nerlich, Carolin and Thimann, Christian, Official Dollarisation/Euroisation: Motives, Features and Policy Implications of Current Cases (February 2004). ECB Occasional Paper No. 11. SSRN: http://ssrn.com/abstract=748975

\section{Glossary}

GDP - Gross Domestic Product

PEF - Programa Estímulo Financiero - Financial Stimulus Program

LOLR - Lender of Last Resort

UNMIK - United Nations Interim Administration Mission in Kosovo

CESS - Central, Eastern and South-Eastern Europe

OeNB - Österreichische Nationalbank (Austrian Central Bank)

RR - Required Reserves of commercial banks

NBS - National Bank of Serbia

REPO - Repurchase Agreement of government securities

RSD - Serbian Dinar

FED - Federal Reserves, Central Bank of United States

ECB - European Central Bank

FOMC - Federal Open Market Comitee

kv1CENEm (q1PRICESm) - Consumer Price Index

kv1EVRO (q1EURO) - Serbian Dinar / Euro exchange rate

BDP rast (GDP growth) - Gross Domestic Product growth

\section{Copyright Disclaimer}

Copyright reserved by the author(s).

This article is an open-access article distributed under the terms and conditions of the Creative Commons Attribution license (http://creativecommons.org/licenses/by/3.0/). 